\title{
Model-Based Quality, Exergy, and Economic Analysis of Fluidized Bed Membrane Reactors
}

\author{
Tabassam Nafees ${ }^{1}$, Adnan Ahmed Bhatti ${ }^{1}$, Usman Khan Jadoon ${ }^{1}{ }^{10}$, Farooq Ahmad ${ }^{2}$, Iftikhar Ahmad ${ }^{1, *}{ }^{\mathbb{C}}$, \\ Manabu Kano ${ }^{3}{ }^{(0)}$, Brenno Castrillon Menezes ${ }^{4}\left(\mathbb{D}\right.$, Muhammad Ahsan ${ }^{1(D)}$ and Naveed ul Hasan Syed ${ }^{5}(1)$
}

1 Department of Chemical Engineering, National University of Sciences and Technology, Islamabad 44000, Pakistan; mahinmuhammad503@gmail.com (T.N.); rizwanbhatti56@gmail.com (A.A.B.); engrusmanjadoon@gmail.com (U.K.J.); ahsan@scme.nust.edu.pk (M.A.)

2 Department of Chemical and Material Engineering, College of Engineering, Northern Border University, KSA, Arar 9280, Saudi Arabia; famin@nbu.edu.sa

3 Department of Systems Science, Graduate School of Informatics, Kyoto University, Kyoto 606-8501, Japan; manabu@human.sys.i.kyoto-u.ac.jp

4 Division of Engineering Management and Decision Sciences, College of Science and Engineering, Hamad Bin Khalifa University, Qatar Foundation, Doha 34110, Qatar; bmenezes@hbku.edu.qa

5 Department of Chemical Engineering, University of Engineering and Technology, Peshawar 25120, Pakistan; syednaveed@uetpeshawar.edu.pk

* Correspondence: iftikhar.salarzai@scme.nust.edu.pk; Tel.: +92-51-90855108

check for

updates

Citation: Nafees, T.; Bhatti, A.A.; Jadoon, U.K.; Ahmad, F.; Ahmad, I.; Kano, M.; Menezes, B.C.; Ahsan, M.; Syed, N.u.H. Model-Based Quality, Exergy, and Economic Analysis of Fluidized Bed Membrane Reactors. Membranes 2021, 11, 765. https:// doi.org/10.3390/membranes11100765

Academic Editors: Ekain Fernandez and Alba Arratibel

Received: 11 August 2021

Accepted: 16 September 2021

Published: 3 October 2021

Publisher's Note: MDPI stays neutral with regard to jurisdictional claims in published maps and institutional affiliations.

Copyright: (c) 2021 by the authors. Licensee MDPI, Basel, Switzerland. This article is an open access article distributed under the terms and conditions of the Creative Commons Attribution (CC BY) license (https:// creativecommons.org/licenses/by/ $4.0 /)$.

\begin{abstract}
In petroleum refineries, naphtha reforming units produce reformate streams and as a by-product, hydrogen $\left(\mathrm{H}_{2}\right)$. Naphtha reforming units traditionally deployed are designed as packed bed reactors (PBR). However, they are restrained by a high-pressure drop, diffusion limitations in the catalyst, and radial and axial gradients of temperature and concentration. A new design using the fluidized bed reactor (FBR) surpasses the issues of the PBR, whereby the incorporation of the membrane can improve the yield of products by selectively removing hydrogen from the reaction side. In this work, a sequential modular simulation (SMS) approach is adopted to simulate the hydrodynamics of a fluidized bed membrane reactor (FBMR) for catalytic reforming of naphtha in Aspen Plus. The reformer reactor is divided into five sections of plug flow reactors and a continuous stirrer tank reactor with the membrane module to simulate the overall FBMR. Similarly, a fluidized bed reactor (FBR), without membrane permeation phenomenon, is also modelled in the Aspen Plus environment for a comparative study with FBMR. In FBMR, the continuous elimination of permeated hydrogen enhanced the production of aromatics compound in the reformate stream. Moreover, the exergy and economic analyses were carried out for both FBR and FBMR.
\end{abstract}

Keywords: naphtha catalytic reforming; two-phase theory of fluidization; fluidized bed membrane reactor; fluidized bed reactor; exergy analysis; economic analysis

\section{Introduction}

Catalytic reforming of naphtha converts low-octane straight-run naphtha, from crudeoil distillation towers, into high-octane reformates. Naphtha reforming has two primary purposes, which are: (1) Production of high-quality octane rating booster to be blended in gasoline streams; and (2) a source of benzene, toluene, xylene isomers (BTX), which are important precursors for further chemical synthesis. As a side effect of the transformations from linear to cycle carbon chain of the hydrocarbon molecules, a considerable amount of hydrogen gas $\left(\mathrm{H}_{2}\right)$ is produced in the process, which is utilized in the refinery (such as in hydrotreating and hydrocracking units) or other applications [1,2].

Although there is a rise in renewable energy resources along with environmental restrictions, the hydrocarbon-based fuel is still widely used, specifically in the transportation sector. The combustion by-products of this fuel have some serious concerns by environmental protection agencies since they are recognized as the leading cause of global 
warming. To mitigate these effects in the environment, fuel utilization legislations require a high-octane number $(\mathrm{ON})$ for high performance of the combustion process, avoiding delays or mismatches between the optimal combustion process and the movement of the vehicle engines [1]. ON is the quality parameter of gasoline streams that shows how much compression it can withstand without knocking in a gasoline engine. The octane number of gasoline streams is conveniently boosted by naphtha catalytic reforming reformates that occur in three or four radial or axial flow fixed packed bed reactors. It is a fixed bed type of reactor in which the catalyst is placed in a dumped arrangement. Whereas the mode of operation is dependent on the design and is classified as semi-regenerative, cyclic or the newer continuous regenerative type based on the mode of the catalyst regeneration stage. In the naphtha reforming, the catalyst particle size is kept at a value in which there is a compromise between the pressure drop and increased surface area. Larger particles provide less resistance to the gas flow, although they have a low particle effectiveness factor [2].

Considering that the reforming reaction in the equilibrium uses straight-run naphtha molecules to yield the reformate plus $\mathrm{H}_{2}$, the desired forward reaction can be boosted by selective removal of the $\mathrm{H}_{2}$ from product gases [3,4]. To improve naphtha reforming and pure hydrogen recovery, membrane assisted fluidized bed reactors are recommended [5,6]. In this study, a fluidized catalyst bed reactor is included with Pd membrane-based walls in the naphtha reforming process. This reactor configuration enables the selective in-situ removal of hydrogen from product gases, which increases the production of aromatics. In the membrane reactor, the walls are replaced by a perm-selective membrane material. The reactor design is very important in this regard for maximum yield and simultaneous in-situ hydrogen recovery $[7,8]$.

The developing membrane reactor technology increases hydrogen production and facilitates higher yields of aromatics, as well. In the reported studies, palladium, and its alloys such as palladium-copper [9], palladium-silver [4,10], and only palladium [8] have been used as membrane reactors. For the synthesis of methanol, Rahimpour proposed membrane reactors with the $\mathrm{Pd}-\mathrm{Ag}$ membrane and pure Pd membrane [11]. Pasha et al. [12] developed FBMR for steam methane reforming in the Aspen Plus environment. Tosti et al. [13] experimented with different configurations of palladium-based membrane reactors for the extraction of ultra-pure hydrogen. Roy et al. [14] worked on the simulation of membranebased fluidized bed reformers and their economic aspects. Khosravanipour and Rahimpour [15] as well as Rahimpour et al. [11] presented the concept of membrane assisted naphtha reformer and studied the effects of in-situ hydrogen separation in a packed bed reactor and fluidized bed reactor for naphtha reforming. Their results showed an enhancement of aromatics along the reactor and studied the effects of combining the endothermic naphtha reforming reaction and hydrogenation of aniline to nitrobenzene in a thermally coupled fluidized bed reactor. Modelling a membrane reactor is a challenging task due to the simultaneous occurrence of diffusion coupled with the mass transfer and chemical reaction inside the reactor [16].

In naphtha reforming, the studies on FBMR that used mathematical and computing programming languages such as MATLAB or FORTRAN are not readily accessible to the design engineers in the process industry. In this study, a FBMR for naphtha reforming is developed on the Aspen Plus platform. Aspen Plus is a widely employed process simulator for industrial process simulations. In the software, the physical phenomena on the FBMR are implemented utilizing the hydrodynamics theory as an integrated sub-model. Additionally, chemical reactions are conveniently implemented by the built-in power-law input panel of Aspen Plus. Ideal reactor models are available as modules in Aspen Plus and are combined successively to mimic the behaviour inside the fluidized bed membrane reactors [17]. An interface to Excel is used for supplying hydrodynamic parameters to Aspen for calculation of volumes and voidage in CSTR and PFR blocks of Aspen Plus. Naphtha reforming is energy intensive process therefore high energy efficiency is desired to improve its feasibility and sustainability. 
The quest of an energy efficient operation has led to the use of exergy (useable energy) to aid in systems engineering design [18]. The exergy-based analysis provides information on the system that comprises multiple domains and disciplines using energy as a common ground, with irreversibilities taken into account [19]. It incorporates the first and second law of thermodynamics and helps in quantifying and minimizing the effect of irreversibility [20]. The exergy and economic analysis of the FBMR and FBR models are performed separately to have a comparative view of the exergy efficiency and economic viability. The Aspen Plus software has been used intensively for a comparative study of FBMR and FBR models, but the exergy analysis was not included in the comparison [21-23]. In this study, the MATLAB based algorithm is used to analyze the exergy efficiency of both FBMR and FBR models.

The paper has been organized as follows. The reforming process is described in Section 2. An industrial setup for a semi-regenerative reformer is taken as an example from the literature, where three packed bed reformers are used. Section 3 details the model building and flow sheeting process in the Aspen Plus environment with Excel interfacing. Results from the simulation are discussed and compared with FBR in Section 4, followed by conclusions in Section 5 .

\section{Process Description}

During the naphtha reforming process, the low-octane hydrocarbons are modified to yield a high-value reformate. Typically, a naphtha reformer feed is a mixture composed of the following: with a boiling point from 30 to $90{ }^{\circ} \mathrm{C}$ is light naphtha (C5 and C6), 90 to $150{ }^{\circ} \mathrm{C}$ is medium-weight naphtha (C7 and C9), and 150 to $200{ }^{\circ} \mathrm{C}$ is heavy naphtha (C9 and C12). The straight-run naphtha constitutes 15 to $30 \mathrm{wt} \%$ of the crude oil. It is obtained directly from the atmospheric crude oil distillation column. Additionally, it is a mixture of paraffin, naphthenes, and aromatics in the $\mathrm{C} 5-\mathrm{C} 12$ range and the boiling point between 30 and $200{ }^{\circ} \mathrm{C}$.

The reformer operating conditions require that the feed be heated at high temperature ( $770 \mathrm{~K}, 3.7 \mathrm{MPa})$. Reactions are carried out under high hydrogen partial pressure to reduce catalyst deactivation due to coking. Typically, 3-4 serially connected fixed bed reactors are employed for reforming with inter-stage heating. The feed gas is pre-heated with the heat exchange from the effluent of the last reactor. Heat exchangers are usually of the shell and tube type. As the reforming reactions are endothermic, the effluent from each reactor requires re-heating to compensate for the temperature drop and the related rate of reaction decline.

As shown in Figure 1, the feed and recycle hydrogen are mixed to attain the desired $\mathrm{H}_{2} / \mathrm{HC}$ ratio and pre-heat the feed stream $[11,24]$. The pre-heated feed is brought to the reaction temperature of $777 \mathrm{~K}$ in the feed heater and is fed to the first reactor. The reactors are loaded with Pt-Re catalysts on an alumina support. The catalyst is bi-functional, where the alumina provides the acid function and Pt-Re provides the metal function for dehydrogenation of naphthenes. The partially reacted effluent from reactor 1 is brought up to the reaction temperature in heater 2 and becomes the feed to reactor 2 . With the passage through the reactors, the rates of reaction drop resulting in the increased reactor volume. There is a notable drop in the endothermicity of the reactions and consequently, the heating requirements also decrease. The product stream from the third reactor is first pre-cooled with the incoming feed and then is sent to a flash separator vessel, where the liquid and gaseous components are separated. Cooling of the product stream is required due to its high temperature. A drop in temperature affects the separation of lighter gases from the reformate liquid. The flashed-gas contains hydrogen along with products of cracking, which are mainly a small quantity of light gases such as methane, ethane, propane, and butane. The hydrogen from the flash separator is split into two parts. One part is compressed and added to the naphtha feed to maintain the inlet $\mathrm{H}_{2} / \mathrm{HC}$ ratio. The liquid product from the bottom is sent to the fractionation section (stabilizer). 


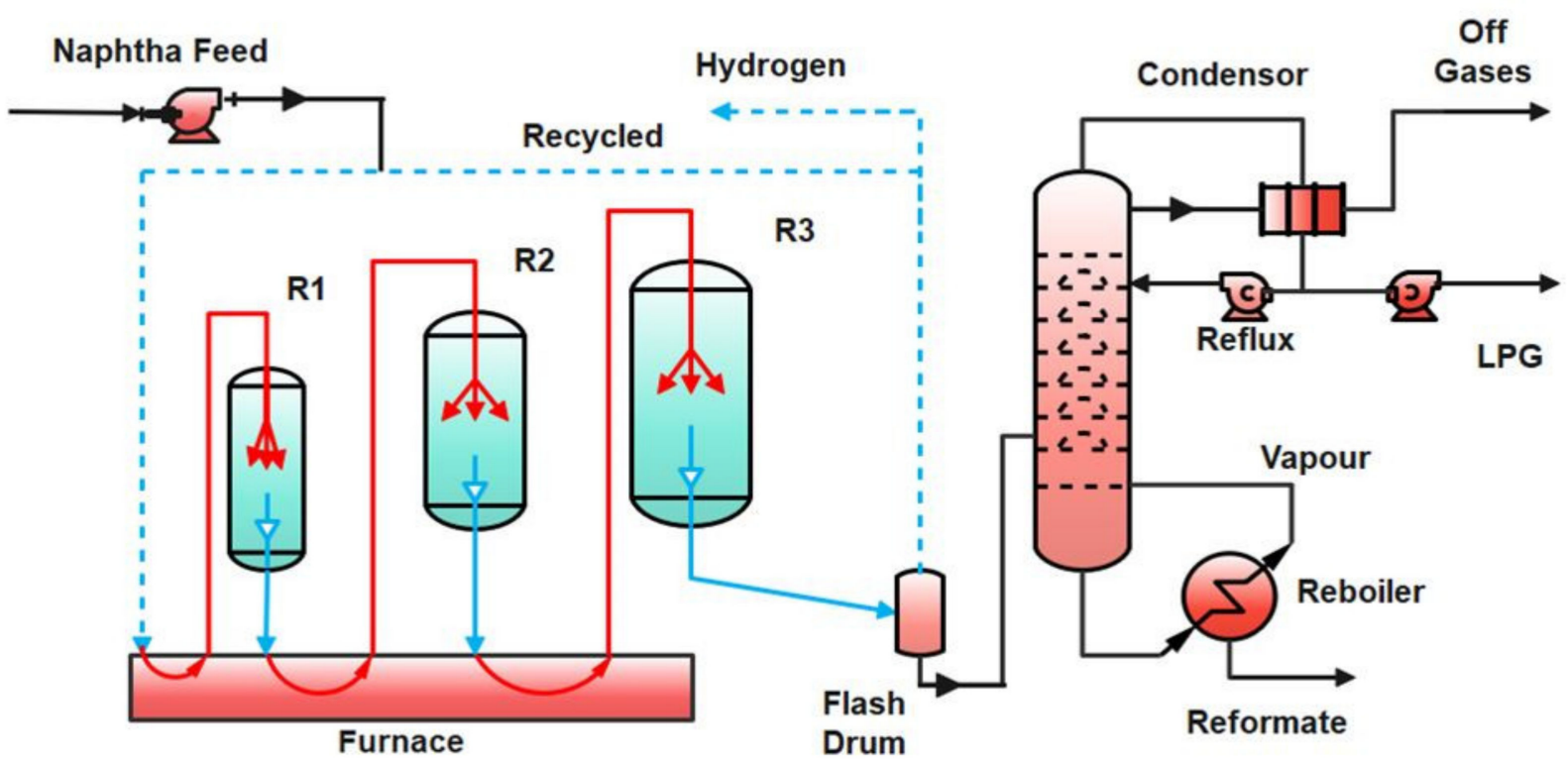

Figure 1. Process flow diagram for the conventional catalytic naphtha reforming process with three reactors (R1, R2, and R3) in series.

The dehydrogenation reaction is the main reaction responsible for the rise of the octane number $(\mathrm{ON})$ value [25]. The temperature drops by almost $50{ }^{\circ} \mathrm{C}$ in the first reactor, which essentially quenches other reactions and thus requires re-heating of the reactants. To maintain the inlet condition of each reactor, a heat exchanger is used to accommodate the changes in pressure and temperature. A bi-functional catalyst is employed for the reforming process. The two functions are metallic and acidic and are needed for different reactions. Hydrogenation and dehydrogenation reactions are catalyzed by the metal function, while the acid function promotes the isomerization and cyclization reactions [26]. The dehydrogenation reaction, which is the dominant reaction has been studied and reported in the literature. The first reported study is from Smith [27], which included dehydrogenation in his four lumped model. Other variations of Smith's model have been proposed later. Marin et al. [28], Ramage et al. [29], Jorge and Eduardo [30], Hu et al. [31], Padmavathi and Chaudhuri [32], and Weifeng et al. [33] have performed detailed studies regarding reforming kinetics. The dehydrogenation reaction scheme is presented in Table 1 [6].

Table 1. Dehydrogenation reactions with the rate constant and heat of reaction data.

\begin{tabular}{|c|c|c|c|c|c|}
\hline \multirow[t]{2}{*}{$\mathbf{A C H} \leftrightarrow \mathbf{A}_{\mathbf{n}}+3 \mathbf{H}_{2}$} & \multirow{2}{*}{$\begin{array}{c}\mathbf{r}_{1 \mathbf{n}=} \mathbf{k}_{1 \mathbf{n}}\left(\mathbf{P}_{\mathrm{ACHn}}-\frac{\mathbf{P}_{\mathrm{An}} \mathbf{P}_{\mathrm{H} 2}^{3}}{\mathbf{K}_{1 \mathbf{n}}}\right) \\
\Delta \mathbf{H}\left(\frac{\mathbf{k J}}{\mathbf{m o l H}_{2}}\right)\end{array}$} & \multicolumn{2}{|c|}{$\begin{array}{c}\mathbf{k}_{1 \mathrm{n}}=\exp \left(\mathrm{a}-\frac{\mathrm{E}}{\mathrm{RT}}\right) \\
\left(\mathrm{kmol} \mathrm{kg}_{\mathrm{cat}} \cdot \mathrm{h}^{-1} \cdot \mathbf{k P a}^{-1}\right)\end{array}$} & \multicolumn{2}{|c|}{$\begin{aligned} \mathbf{K}_{1 \mathbf{n}}= & \exp \left(\mathbf{A}-\frac{\mathbf{B}}{\mathbf{T}}\right) \\
& (\mathbf{k P a})^{3}\end{aligned}$} \\
\hline & & $\mathbf{a}$ & $\frac{E}{R} \times 10^{-3}$ & A & B \\
\hline $\mathrm{C}_{6}$ & 68.73 & 18.75 & 19.50 & 59.90 & 24,800 \\
\hline $\mathrm{C}_{7}$ & 208.47 & 20.70 & 19.50 & 60.23 & 25,080 \\
\hline \multicolumn{6}{|l|}{$\mathrm{C}_{8}$} \\
\hline for $\mathrm{A}_{\mathrm{n}}=\mathrm{MX} *$ & 64.50 & 17.89 & 19.50 & 60.37 & 23,270 \\
\hline for $\mathrm{A}_{\mathrm{n}}=\mathrm{OX} *$ & 65.10 & 19.15 & 19.50 & 60.32 & 23,490 \\
\hline for $\mathrm{A}_{\mathrm{n}}=\mathrm{PX} *$ & 64.74 & 18.66 & 19.50 & 60.13 & 23,360 \\
\hline for $\mathrm{A}_{\mathrm{n}}=\mathrm{EB} *$ & 68.70 & 18.71 & 19.50 & 60.40 & 24,780 \\
\hline $\mathrm{C} 9+$ & 66.05 & 20.38 & 19.50 & 61.05 & 21,330 \\
\hline
\end{tabular}

* Improvements made to the Padmavathi et al. model. 


\section{Modelling and Analysis Methods}

\subsection{Membrane Reactor and its Modelling Method}

To fluidize a fixed bed, the catalyst particles are crushed to a small size (100 microns). This is found in the FBMR scheme for naphtha reforming, as depicted in Figure 2 [11] "reproduced with permission from M.R. Rahimpour, international journal of hydrogen energy; published by Elsevier, 2009". During the reforming process, the heat and mass transfer occur within the reactor creating a hydrogen partial pressure gradient that results in a net transfer of hydrogen to the shell side. This transfer of excess hydrogen results in displacing the reaction towards the formation of more product. The fluidization of catalyst particles is carried out by feeding the catalyst filled reactor with gas from the bottom through a porous plate distributor. Hydrogen gas is used as a sweep gas in the shell compartment, where its flow is co-current with the reactant gas. Fluidization results in a very low-pressure drop even using a very small catalyst size, which would not be feasible in a fixed bed. The membrane material of selection is a palladium-silver alloy combining the excellent perm selectivity of palladium with silver providing mechanical stability. Hydrogen gas in the product permeates through the membrane surface. This permeation results in the displacement of equilibrium in the forward direction. In this reactor configuration, reformate and hydrogen production increases as hydrogen is being separated from each reactor. The hydrogen yields consequently decrease owing to the compositional difference with the fixed bed reactor. The hydrogen permeation process is shown in Figure 3 [34] "reproduced with permission from Samhun Yun, journal of membrane sciences; published by Elsevier, 2011". To control the hydrogen permeation, pressure is used as a driving force in the shell side of each reactor. The thickness of the dense membrane for modelling in Aspen Plus v11.0 is set to $20 \mu \mathrm{m}$ and is mounted with a stainless-steel support. The membrane's length is equal to $6.29,7.13$, and $7.89 \mathrm{~m}$ and the area is $30.02,37.39$, and $49.05 \mathrm{~m}^{2}$ for reactor 1,2 , and 3, respectively [6].

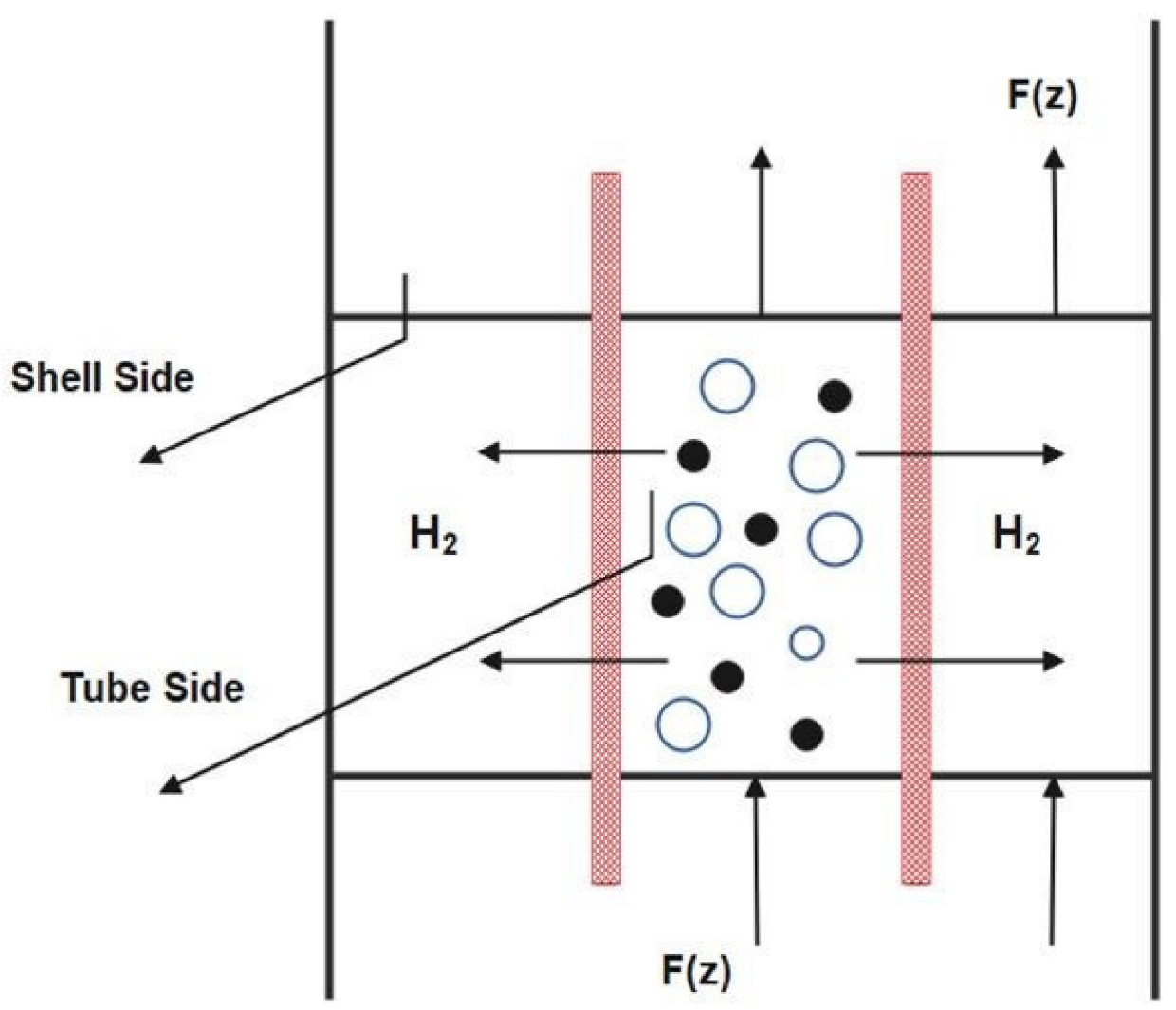

Figure 2. Cross sectional view of Fluidized bed membrane reactor model. 


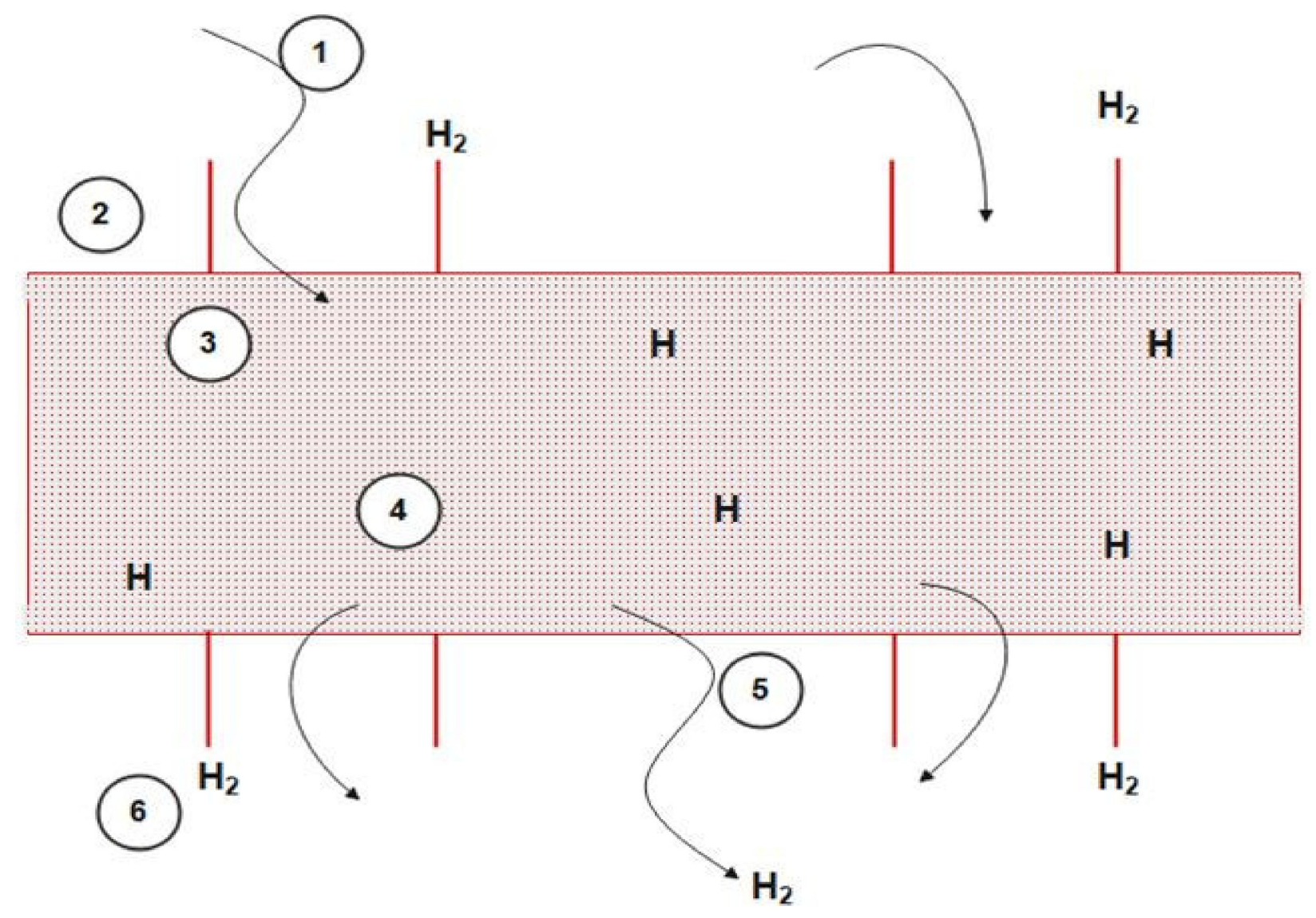

Figure 3. Hydrogen permeation from membrane.

An Excel calculator block integrated into Aspen Plus is developed for the calculation of hydrodynamic parameters, using the two-phase theory of fluidization that calculates the catalyst weight, as well as the distribution and volume of CSTR and PFR combination.

\subsection{Preliminary Assumptions}

- The dense catalyst bed has two identifiable phases: A bubble phase and an emulsion phase.

- $\quad$ Steady-state and pseudo-steady-state operation is assumed.

- Much of the reactions occur within the emulsion phase.

- Permeation of hydrogen is assumed to occur from the emulsion phase only.

- Hydrogen diffuses through the membrane radially.

- Assumption of spherical bubbles hold.

- The movement of gas in bubbles is assumed to follow the plug flow. Additionally, due to a very low quantity of catalyst, the reaction rates are very low compared to the emulsion gas phase velocity.

- Contents of the bed are well mixed and both emulsion and bubble phases are at a uniform temperature.

- Adiabatic conditions.

- $\quad$ Sieverts' law is applicable for hydrogen permeation through the membrane [35] (Equation (1)).

$$
Q_{H_{2}}=\eta k C_{m p}\left[P_{R H_{2}}^{0.5}-P_{M H_{2}}^{0.5}\right] e^{\left(-\frac{E a}{R T}\right)}
$$

The Aspen Plus based model simulation of FBMR and FBR is performed and detail results are reported in Section 4. The equations used from the literature are presented in Table 2 [36]. The output from the block is transferred to CSTR and PFR units through an 
internal Excel interface and transfer modules. A fluidized bed exhibits complex hydrodynamics. To model its behavior, the dense bed is divided into a bubble phase and an emulsion phase. Membrane permeation occurs simultaneously with the reaction. Gas flowing in the form of bubbles is modelled through a plug flow reactor and the emulsion phase is modelled through CSTR. The fluidized bed reactor is represented by PFR and CSTR, which are available standard modules in Aspen Plus. A separate 'SPLT' Excel file is used to implement the equations described in Table 2. After estimating the hydrodynamic parameters, the data are transferred to Aspen Plus, which uses its internal database to calculate the thermodynamic properties based on material and energy balance equations. The effluent streams from each section are then transferred to the 'TRF' Excel block, where the mass transfer equation (in the case of FBR) and additionally Sievert's equation (in the case of FBMR) are implemented. Afterwards, the exit streams are transferred to the respective PFR and CSTR for the next section (i+1). Calculations then proceed in this manner until they reach the topmost section of the bed.

Table 2. Parameters for hydrodynamic calculation>.

\begin{tabular}{|c|c|}
\hline Studied Parameter & Model Equation \\
\hline $\begin{array}{l}\text { Superficial velocity at minimum } \\
\text { fluidization }\end{array}$ & $\frac{1.75}{\epsilon_{m f}^{3} \varphi_{s}}\left[\frac{d_{p} \rho_{g} u_{m f}}{\mu}\right]^{2}+\frac{150\left(1-\epsilon_{m f}\right)}{\epsilon_{m f}^{3} \varphi_{s}}\left[\frac{d_{p} \rho_{g} u_{m f}}{\mu}\right]=A r$ \\
\hline Archimedes' number & $A r=\frac{d_{p}^{3} \rho_{g}\left(\rho_{p}-\rho_{g}\right) g}{\mu^{2}}$ \\
\hline Bubble diameter & $\begin{array}{c}d_{b}=d_{b m}\left(d_{b m}-d_{b 0}\right) \exp (-0.3 z / D) \\
d_{b 0}=0.376\left(u_{0}-u_{m f}\right)^{2} \\
d_{b m}=0.65\left[\frac{\pi}{4} D^{2}\left(u_{0}-u_{m f}\right)\right]^{0.4}\end{array}$ \\
\hline $\begin{array}{l}\text { Coefficient of mass transfer } \\
\text { (Bubble to emulsion phase) }\end{array}$ & $K_{b e}=\frac{u_{m f}}{3}\left[\left(\frac{4 D_{j m} \epsilon_{m f} u_{b}}{\left(\pi d_{b}\right)}\right)\right]^{1 / 2}$ \\
\hline The velocity of bubble rise & $u_{b}=u-u_{m f}+0.711 \sqrt{g d_{b}}$ \\
\hline $\begin{array}{l}\text { The volume fraction of the bubble phase to } \\
\text { the overall bed }\end{array}$ & $\delta=\frac{\left(u-u_{m f}\right)}{u_{b}}$ \\
\hline Specific surface area for bubble & $a_{b}=\frac{6 \delta}{d_{b}}$ \\
\hline Density for emulsion phase & $\rho_{e}=\rho_{p}\left(1-\epsilon_{m f}\right)$ \\
\hline
\end{tabular}

The membrane performance is affected by non-uniformity in the membrane fabrication and blockage of the membrane surface by catalyst dust. The membrane permeation effectiveness factor $(\eta)$ accounts for all the negative influences on the permeation rate and its value is determined experimentally [4]. To simulate the hydrogen permeation process through the membrane tube, a User Model 2-unit operation block with an Excel spreadsheet is used to perform the calculations. Aspen Plus supplies the properties of the feed stream of the user model and some additional parameters $\left(\eta, \mathrm{k}, \mathrm{C} \mathrm{mp}, \mathrm{E}, \mathrm{R}, \mathrm{T}, \mathrm{P}_{\mathrm{RH}_{2}}\right.$, and $\left.\mathrm{P}_{\mathrm{MH}_{2}}\right)$ to the Excel spreadsheet. The additional parameters are shown in Table 2. Excel organizes this information and calculates the product stream properties with the hydrogen production rate $\left(Q_{\mathrm{H}_{2}}\right)$ based on Sieverts' law. This information is then returned to the Aspen Plus interface and results are displayed. The effect of increasing the number of stages is an increase in the transfer of partially reacted bubble gas to emulsion gas, where higher chances for the reaction exist. The right number of stages to model this system is dependent on its kinetics and hydrodynamics.

\subsection{Exergy Analysis}

Exergy is the maximum amount of work available by bringing the source through the reversible process into its equilibrium with its environment. It is also known as the ability of energy to do valuable work [18]. The maximum amount of output work occurs when 
the system gains equilibrium reversibly. However, the actual work is quite smaller due to process irreversibility [37].

Physical exergy, considered in this study, of a stream is exergy arising from the difference of the actual temperature and pressure condition $(T, P)$ from reference values $\left(T_{o}, P_{o}\right)$. As shown in Figure 4, physical exergy represents the thermomechanical part of total exergy [21]. The physical exergy term can be expressed in the equation below.

$E x=E x^{p h y}=\Delta_{\text {actual } \rightarrow 0}\left[L\left(\sum_{i=1}^{n} \cdot x_{i} H_{i}^{l}-T_{0} \sum_{i=1}^{n} \cdot x_{i} S_{i}^{l}\right)+V\left(\sum_{i=1}^{n} \cdot x_{i} H_{i}^{v}-T_{0} \sum_{i=1}^{n} \cdot x_{i} S_{i}^{v}\right)\right]$

Actual Conditions

$(\mathrm{T}, \mathrm{P})$

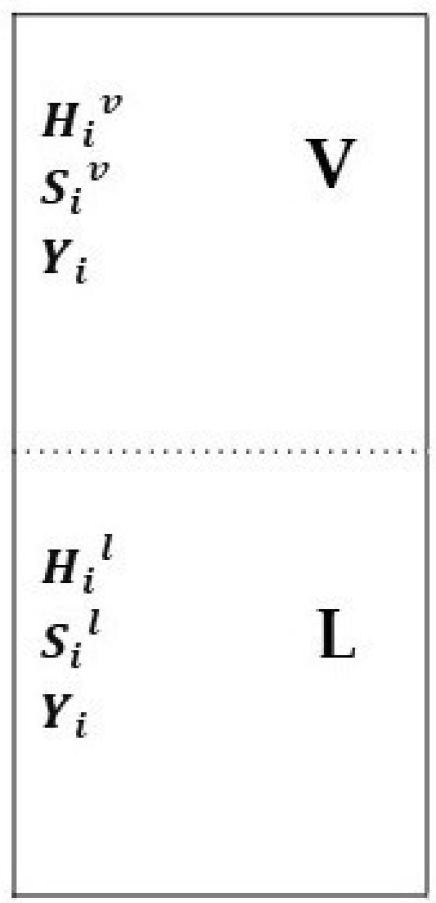

\section{Reference Conditions}

$\left(\mathrm{T}_{\circ}, \mathrm{P}_{\circ}\right)$

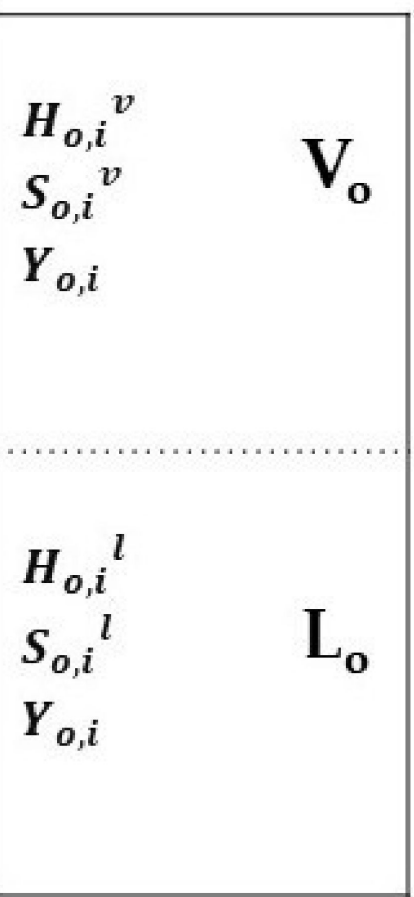

Figure 4. Exergy change from actual to reference conditions.

For the physical exergy calculation, the enthalpy and entropy at a certain reference condition are required. Where $H_{i}^{l}$ and $S_{i}^{l}$ are the enthalpy and entropy in the liquid phase, while $H_{i}^{v}$ and $S_{i}^{v}$ are the enthalpy and entropy in the vapour phase, transition depicted in Figure 4. Additionally, $T_{o}$ is the temperature at the reference condition.

\subsection{Economic Analysis}

For the economics of a process design, there are three fundamental rules: (a) Estimation of the design options, (b) optimization of the process operations, and (c) overall project profitability. The total cost required for a new project can be divided into five main points.

Battery limit investment: Battery limit denotes the geographic boundary that describes the manufacturing area of a process plant. It encompasses structure, equipment, and buildings. The battery limit investment involves the acquisition of every distinct plant item and its installation that makes up a working process. The cost of certain equipment depends on the capacity, material of construction, design and operating pressure, and 
temperature of equipment. Cost data can be taken from capacity versus cost charts or power law [38].

$$
C_{E Q P}=C_{B A S E}\left(\frac{Q}{Q_{B A S E}}\right)^{Z}
$$

where $C_{E Q P}$ is the cost of the equipment with capacity $Q, C_{B A S E}$ is the cost of the equipment with base capacity $Q_{B A S E}, Z$ is constant and depends on the type of equipment, and $A$ is the larger amount of the published data, which is available in the literature. The published data are mostly old, require an update, and can be put on a common basis using indexes [39].

$$
\frac{C_{Y 1}}{C_{Y 2}}=\frac{I_{Y 1}}{I_{Y 2}}
$$

where $C_{Y 1}$ and $C_{Y 2}$ are the costs in the first and second years, respectively. Moreover, $I_{Y 1}$ and $I_{Y 2}$ are the indices in the first and second years, respectively.

Commonly used indices are the Chemical Engineering Indexes and Marshall and Swift, published in the Chemical Engineering magazine, whereas the Nelson-Farrar Cost Indexes for refinery construction are published in the Oil and Gas Journal [38]. The Chemical Engineering Process Cost Index (CEPCI) is widely used in process industries [39]. Finally, the material of construction, the pressure, and the temperature of the design affect the cost of equipment. The capital cost factors for typical material of construction, pressure, and temperature are given in the literature $[3,40]$.

$$
C_{E Q P}=C_{B A S E}\left(\frac{Q}{Q_{B A S E}}\right)^{Z} f_{M A T} f_{P R E} f_{T F M}
$$

where $f_{M A T}$ is the correction factor for MOC, $f_{P R E}$ is the correction factor for pressure. Additionally, $f_{T E M}$ is the correction factor for temperature

Utility investment: Capital cost in utility includes generation and distribution of electricity, process water, refrigeration, and compressed water.

Off-site investment: This includes roads and paths, guardhouses, warehouses, and loading and weighment devices.

Working capital: The expenses which are invested prior to any production. It includes product inventories, material transportation cost for start-up, and credits extended to customers and suppliers.

Total capital cost: The total capital cost of the process, services, and working capital can be obtained by applying multiplying factors or installation factors to the purchase cost of individual items of equipment [41]. The capital cost of the Pd-Ag based membrane and stainless-steel frame is taken from the experimental investigations carried out by US-DOE [42].

$$
C_{F I X}=\sum f_{I} C_{E Q P, I}
$$

where $C_{F I X}$ is the fixed capital cost of a complete project.

The installation factor for the new design is broken down in Table 3 into constituent parts, according to the governing phase being processed. Therefore, for the installation factors, the application and estimation of the total capital cost in the following equation is used $[42,43]$.

$$
C_{F I X}=\sum\left[f_{M A T} f_{P R E} f_{T E M}\left(1+f_{P I P I N G}\right)\right]_{I} C_{E Q P, I}+\left(f_{E Q P R}+f_{I N S T R}+f_{\text {UTILITY }}+f_{O f f S}+f_{B U I L D}+f_{D E C O N C}+f_{C O N T}+f_{\text {WRKS }}\right) \sum C_{E Q P, I}
$$


Table 3. Installation factors for the capital cost of equipment.

\begin{tabular}{|c|c|}
\hline \multicolumn{2}{|c|}{ Capital Cost for Fluid Processing } \\
\hline Item & Factor \\
\hline \multicolumn{2}{|c|}{ Direct costs } \\
\hline Equipment delivered cost & 1 \\
\hline Equipment erection, fEQPR & 0.4 \\
\hline Piping (installed), fPIPING & 0.7 \\
\hline $\begin{array}{l}\text { Instrumentation and controls (installed), } \\
\text { fINSTR }\end{array}$ & 0.2 \\
\hline Electrical (installed), fELEC & 0.1 \\
\hline Utilities, fUTILITY & 0.5 \\
\hline Off-sites, fOffS & 0.2 \\
\hline Buildings (including services), fBUILD & 0.2 \\
\hline Site preparation, fSiteP & 0.1 \\
\hline The total capital cost of installed equipment & 3.4 \\
\hline \multicolumn{2}{|c|}{ Indirect costs } \\
\hline $\begin{array}{l}\text { Design, engineering, and construction, } \\
\text { fDECONC }\end{array}$ & 1 \\
\hline $\begin{array}{l}\text { Contingency (about } 10 \% \text { of fixed capital costs), } \\
\text { fCONT }\end{array}$ & 0.4 \\
\hline Total fixed capital cost & 4.8 \\
\hline \multicolumn{2}{|c|}{ Working capital } \\
\hline $\begin{array}{c}\text { Working capital ( } 15 \% \text { of the total capital cost), } \\
\text { fWRKC }\end{array}$ & 0.7 \\
\hline Total capital cost, f I & 5.8 \\
\hline
\end{tabular}

\section{Results and Discussion}

\subsection{FBMR vs. FBR Model Design}

The reformer is divided into five sections to simulate the conditions inside a real-world operational unit. Figure 5 shows that, as the number of stages is increased, the rate of reaction increases. For the FBMR, the optimum number of stages was determined to be 5 . The Aspen Plus based process flow diagram of FBMR and FBR is given in Figures 6 and 7 , respectively.

\subsection{Parametric Analysis}

Several variables affect the performance of reactors on FBMR. The more important parameters are the temperature at which the reaction is carried out, the pressure of the shell side, and the hydrogen to hydrocarbon molar ratio.

\subsubsection{Influence of Reactor Temperature}

Since the reactions are highly endothermic in nature and thus high temperature favours it. In Figure 8, it is shown that a temperature rise has a favourable impact on the aromatics' mole fraction. As the reaction proceeds inside the reactor the temperature will drop and the reaction rate will decrease due to its endothermic nature. Therefore, the reaction is carried out in three separate adiabatic reactor vessels with varying catalyst amounts. Additionally, inter-stage heaters are provided to re-heat the product stream to the reaction temperature. A similar trend is mentioned by Rahimpour [6], in which 
the membrane-based fluidized reactor has increased production than the conventional fluidized reactor.

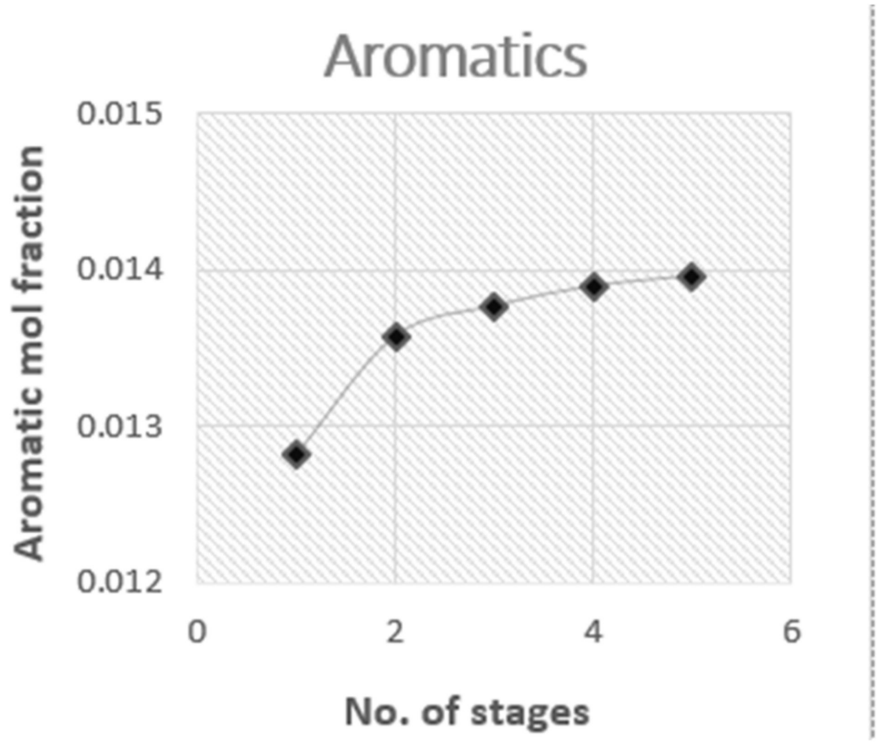

(a)

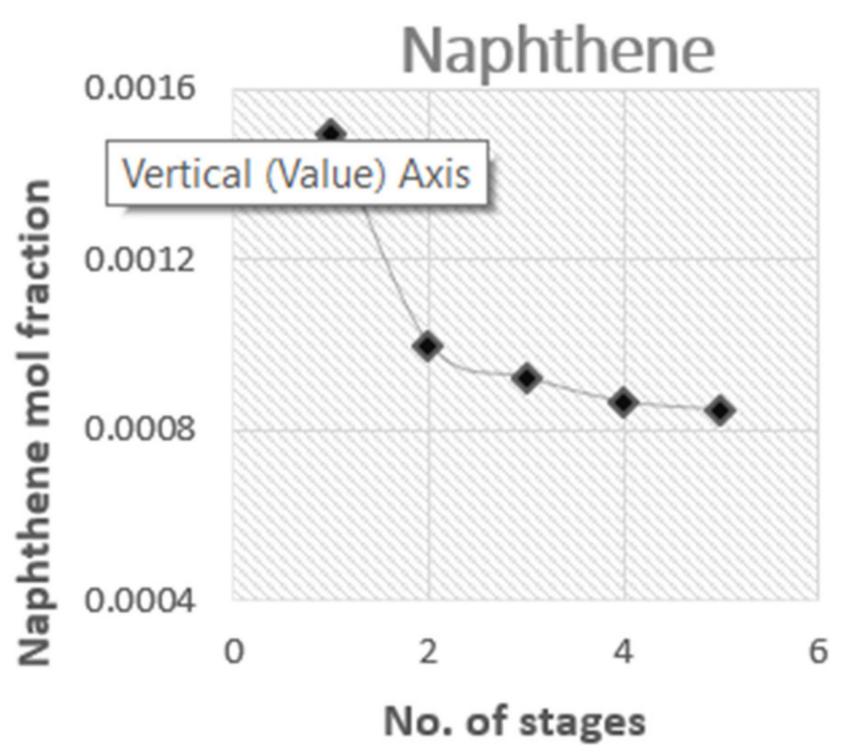

(b)

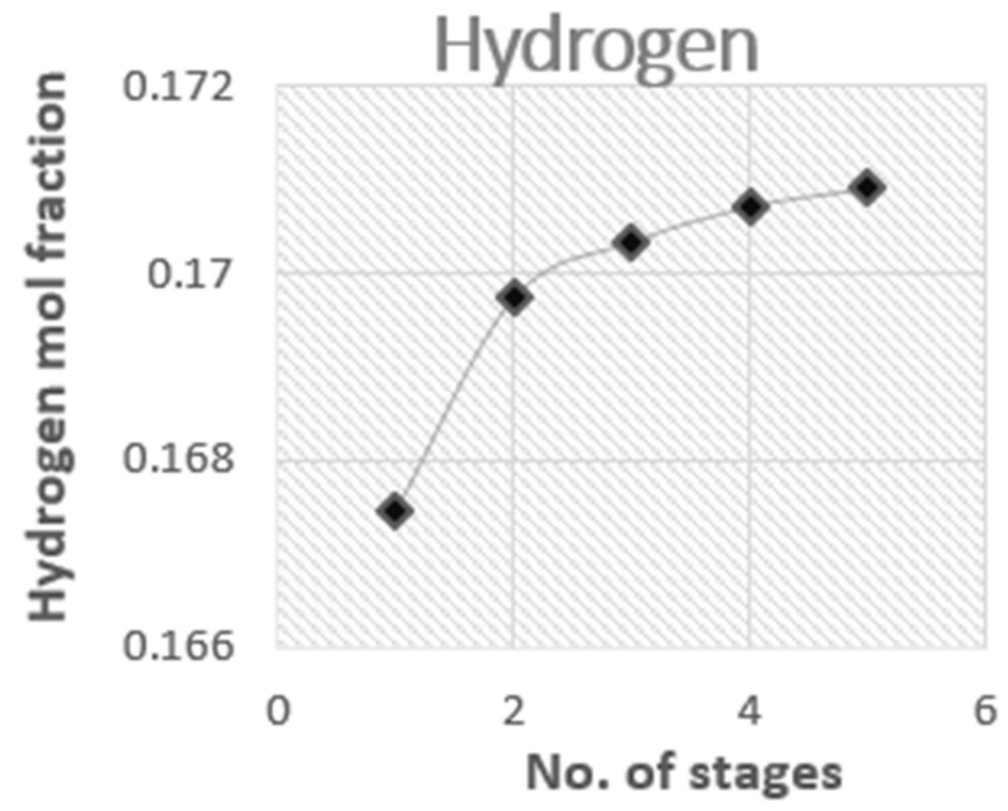

(c)

Figure 5. Effect of the number of stages on FBMR for (a) aromatics; (b) naphthene; (c) hydrogen.

\subsubsection{Influence of Shell-Side Pressure}

The difference between the pressure of reaction side and permeate side creates a driving force for hydrogen permeation. As the dehydrogenation reaction is the hydrogen producer, with the reaction proceeding more and more hydrogen will be produced. In the case of FBR, this hydrogen accumulates inside the reactor and increases its partial pressure as well as increases the affinity for products to move towards the left side, i.e., increasing the moles of reactants. Rahimpour [6] showed that in a traditional FBR, the aromatic mole fraction at $2300 \mathrm{kPa}$ is equal to 0.043 . According to Figure $9 \mathrm{a}$ when the pressure of shell side 
is approximately less than $2300 \mathrm{kPa}$, the aromatic mole fraction is higher than 0.043 . This figure shows that the trend must be followed in shell pressure reduction to have aromatic mole fractions greater than tradiotional FBR. Moreover, in the case of the FBMR, the excess hydrogen is removed alongside the wall, and thus keeps its partial pressure constant or even decreases it if the shell side pressure is further reduced. This is the main reason that the FBMR produces more hydrogen as compared to FBR, due to the increased rate of the forward reaction, as shown in Figure $9 \mathrm{~b}$. While the pressure inside the reactor is controlled within narrow limits, the pressure inside the shell is varied. As a result, hydrogen and thus aromatic production are controlled in the FBMR. Wieland et al. [43] showed that the Pd-Ag membrane achieved maximum theoretical recovery of hydrogen on the increased pressure for hydrogen production and recovery through membrane reactors.

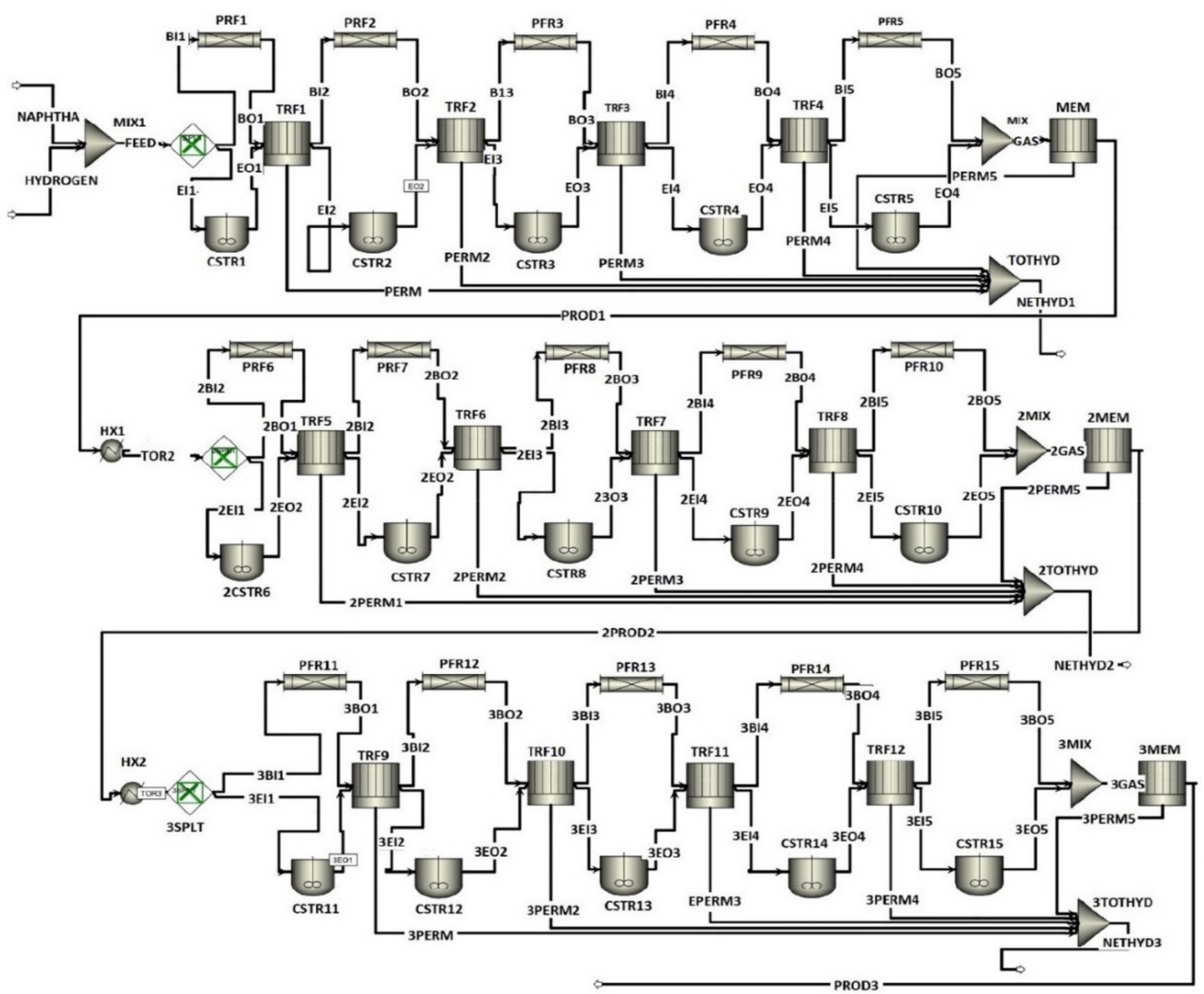

Figure 6. Process flow diagram of FBMR. 


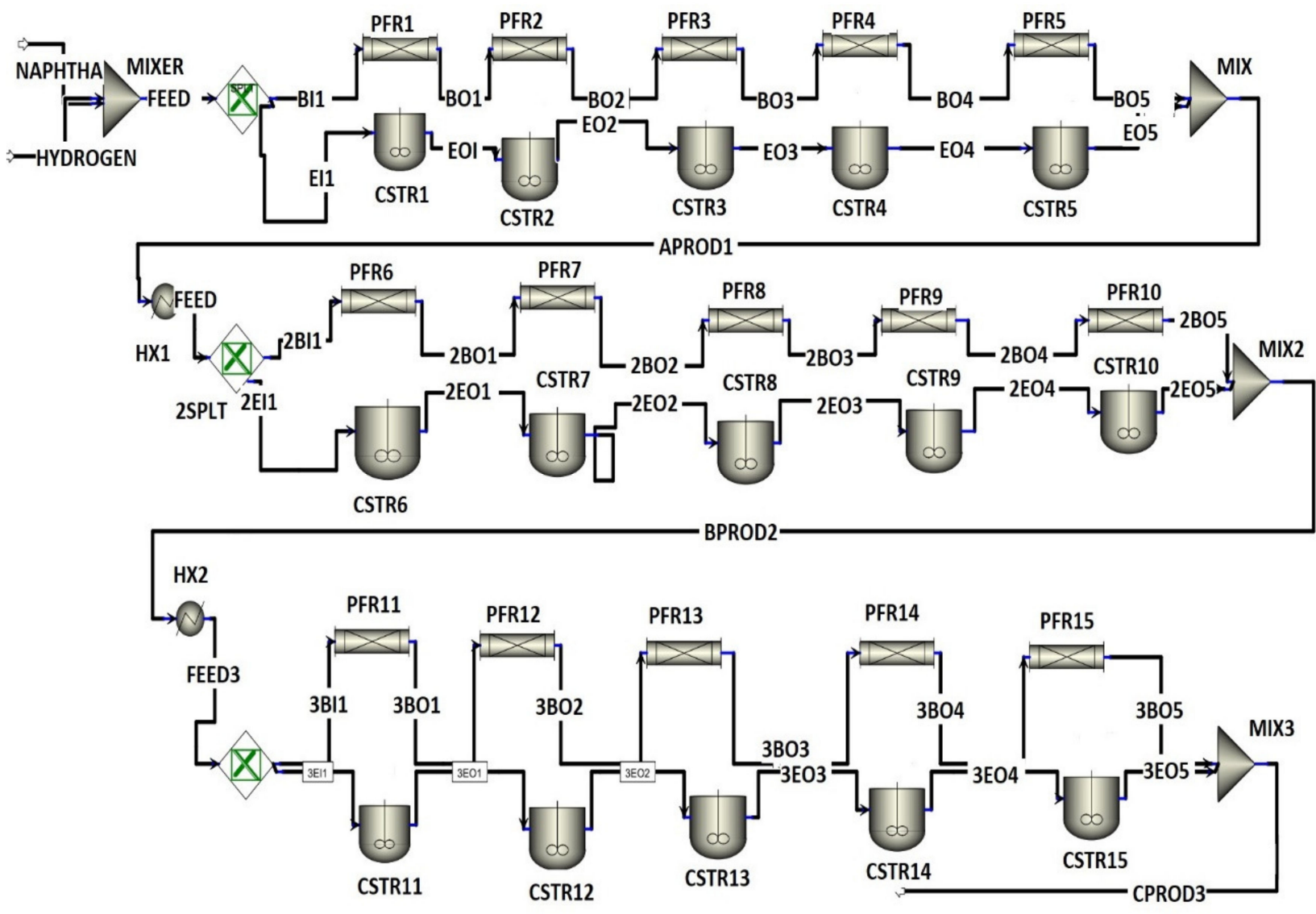

Figure 7. Process flow diagram of FBR.

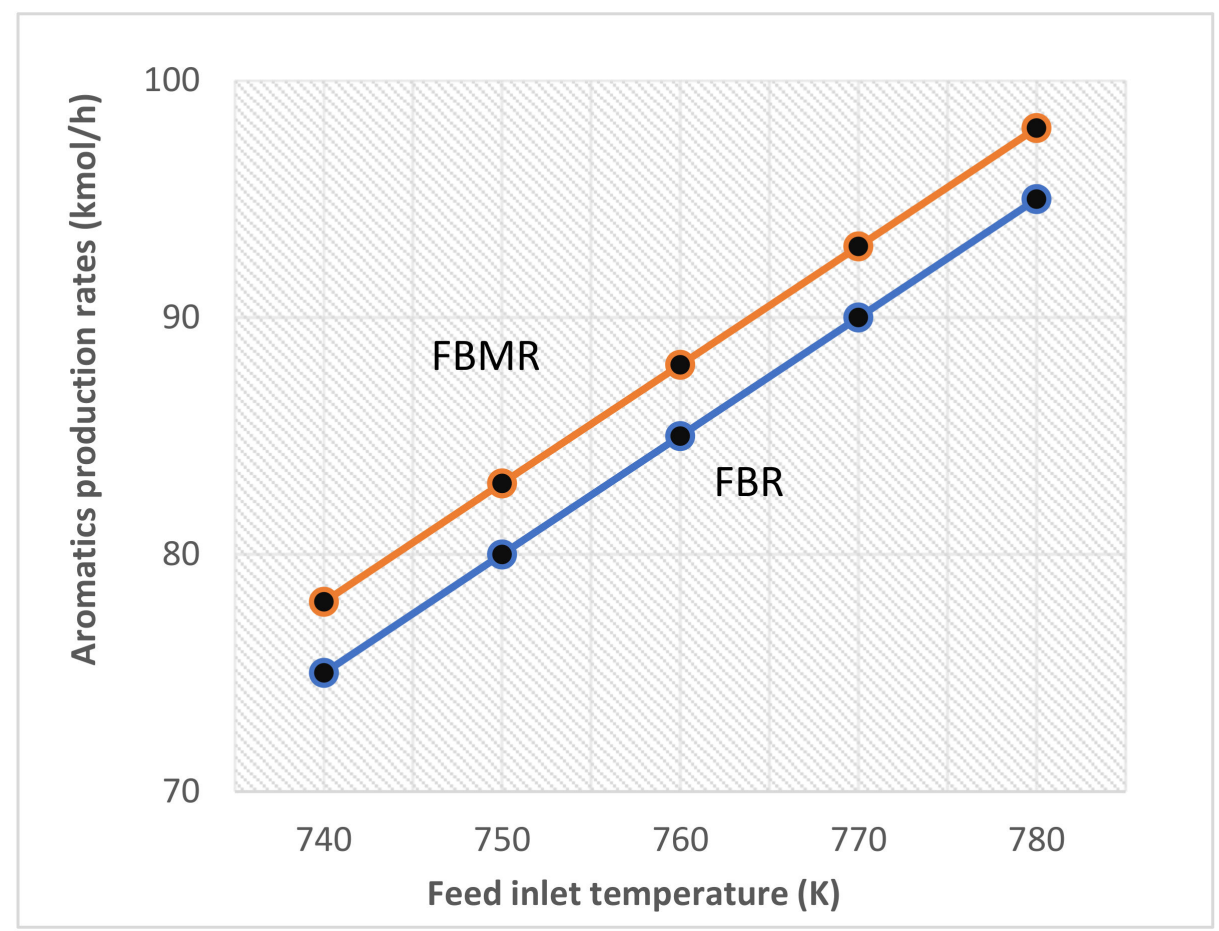

Figure 8. Effect of temperature on aromatic production. 


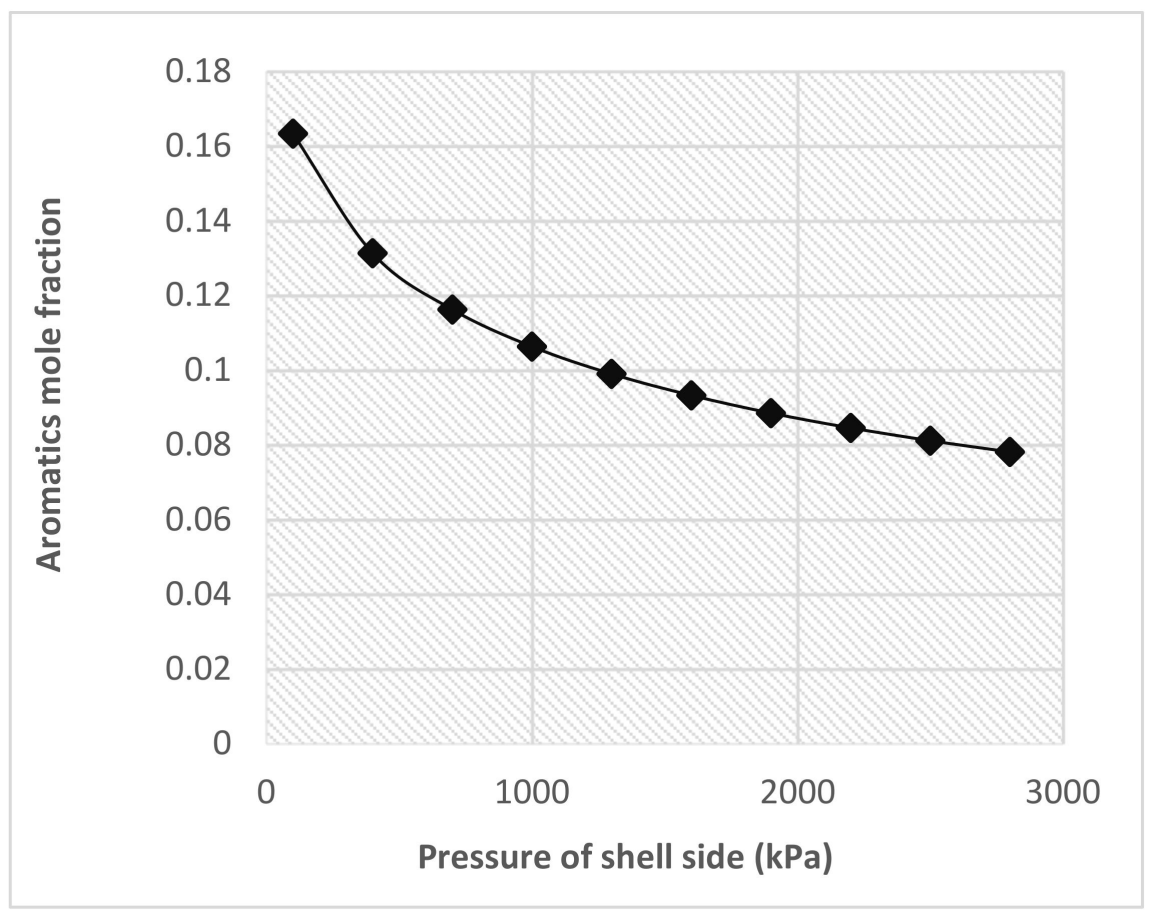

(a)

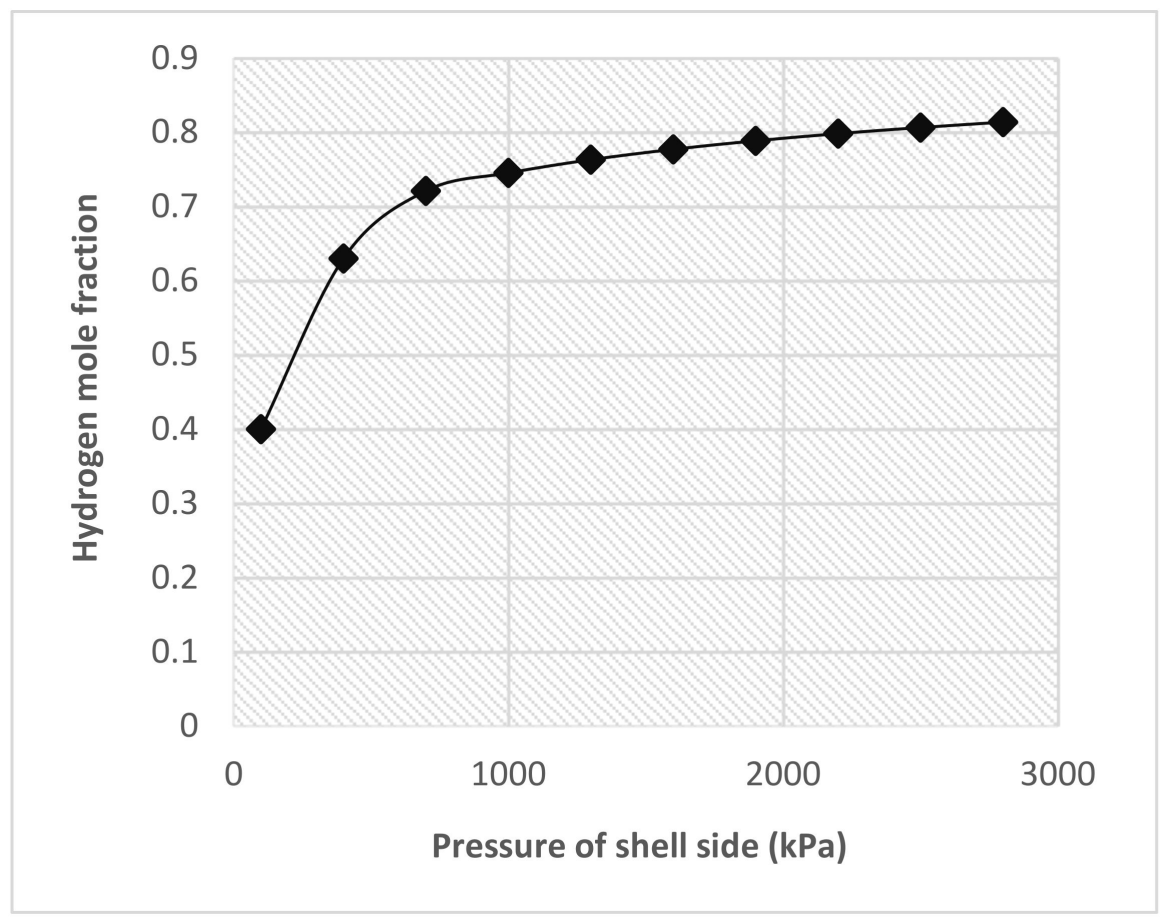

(b)

Figure 9. (a) Mole fraction of aromatic; and (b) mole fraction of outlet hydrogen in the reaction side as a function of shell side pressure.

\subsubsection{Influence of Membrane Thickness}

The effect of membrane thickness on the molar aromatic production is investigated. The result is plotted in Figure 10a. When the membrane is very thin around 10 microns, aromatic production shows a sharp increase with further reduction in thickness. Furthermore, it is observed that when the thickness is about 50 microns, a further increase in 
thickness does not bring any significant reduction in aromatic molar production. The thin membrane requires a support material. Stainless steel and alumina are the more frequently used materials for providing support. Alloying with silver is also a technique to provide mechanical strength. Tong et al. [44] investigated hydrogen recovery through palladium membranes of different thicknesses and reported that the recovery rate almost gets doubled using the 8-micron membrane comparatively to the 11-micron membrane at the same parametric conditions.

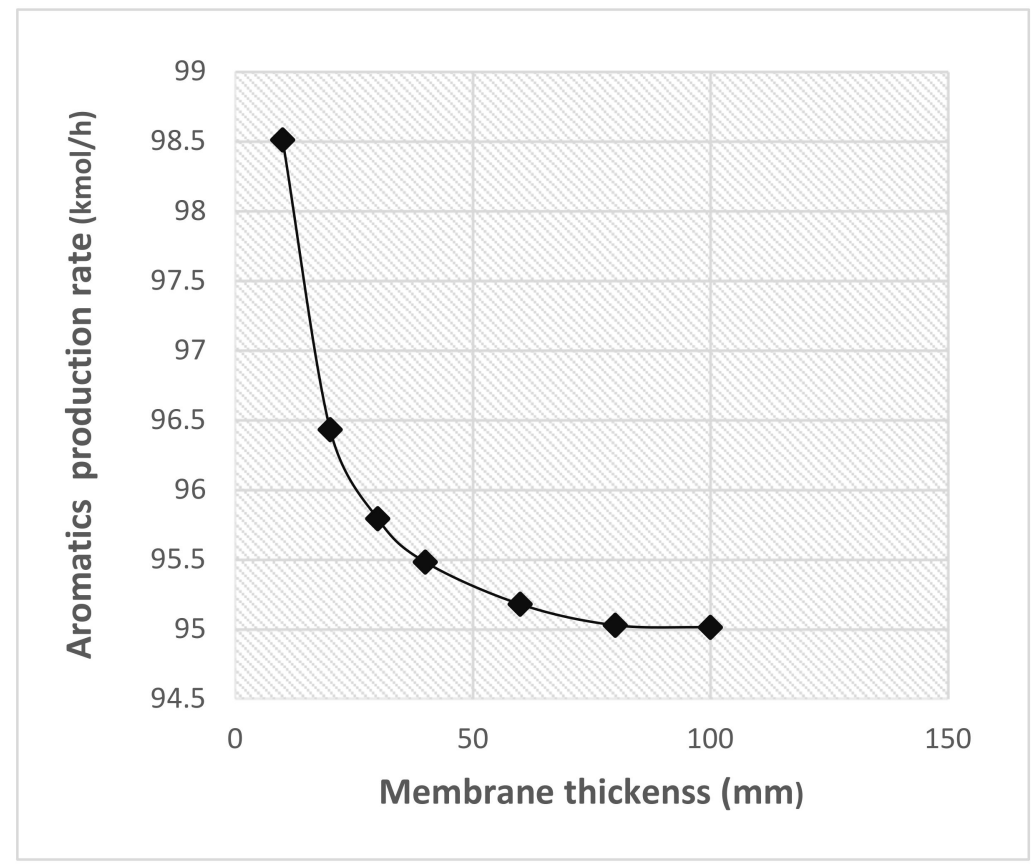

(a)

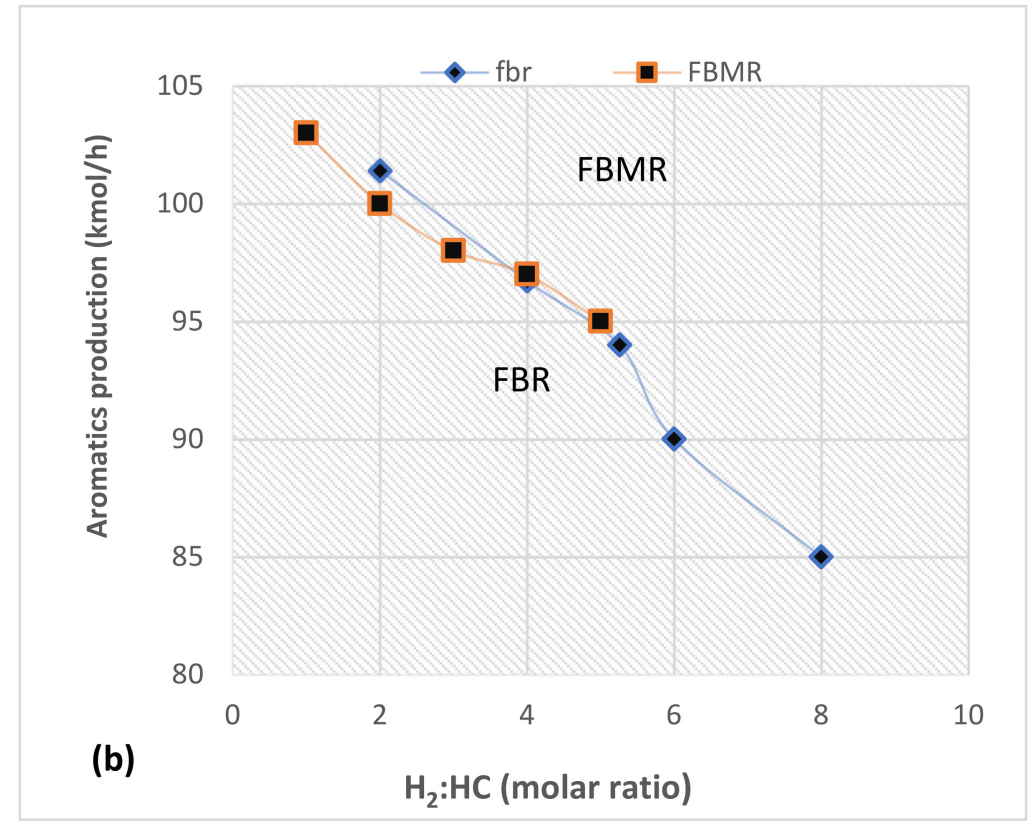

(b)

Figure 10. (a) Aromatic production as a function of the membrane; (b) aromatic production rate vs. $\mathrm{H}_{2} / \mathrm{HC}$ ratio.4.2.4. Influence of $\mathrm{H}_{2} / \mathrm{HC}$ 
The naphtha reforming reactions proceed under a hydrogen atmosphere to suppress the undesired cracking reactions. The hydrogen to hydrocarbon molar ratio is an important parameter from an industrial standpoint. Therefore, its variation on aromatic production is included in this study. The higher hydrogen to hydrocarbon ratio results in the lower aromatic molar production, which can be seen in Figure $10 \mathrm{~b}$. The effect of a high $\mathrm{H}_{2} / \mathrm{HC}$ ratio is more in the case of FBR as compared to FBMR. The higher molar ratio in FBMR is due to the continuous in-situ hydrogen removal, which keeps the aromatic molar flow rate higher than FBR.

\subsection{Aromatics and Hydrogen Yields}

In Table 4, the component-wise yield through the FBR and FBMR is compared. The first column shows the individual hydrocarbon components fed to both reactors. The second column gives the mole fraction of each component, whereas the next column is the product flow rate of FBR (CPROD3) and FBMR (PROD3). In the case of FBMR, part of the hydrogen is continuously removed resulting in a higher production rate of aromatics. Simultaneously, a portion of the pure hydrogen is recycled back to reactors 2 and 3 to maintain the hydrogen to hydrocarbons ratio $\left(\mathrm{H}_{2}: \mathrm{HC}=5.69: 1\right)$. The product streams of the FBMR and FBR show a very significant difference of aromatics and reformates production along with off-gases and hydrogen production yields. As per Rahimpour [6], the hydrogen partial pressure is directly related to the hydrogen to hydrocarbon ratio. The low hydrogen to hydrocarbon ratio leads to coke formation. Therefore, the hydrogen to hydrocarbon ratio should be held at a reasonable value, as it is crucial to maintain their molar ratio.

Table 4. Aromatics production in fluidized bed reactor and fluidized bed membrane reactor.

\begin{tabular}{|c|c|c|c|}
\hline \multirow{2}{*}{ Components } & FEED & FBR (CPROD3) & FBMR (PROD3) \\
\hline & Mole Fractions & kmol/h & $\mathrm{kmol} / \mathrm{h}$ \\
\hline METHA-01 & 0.0089 & 17.14 & 202.537 \\
\hline ETHAN-01 & 0.0098 & 18.76 & 66.443 \\
\hline PROPA-01 & 0.0085 & 16.41 & 16.405 \\
\hline N-BUT-01 & 0.0045 & 8.60 & 8.590 \\
\hline ISOBU-01 & 0.0031 & 5.94 & 5.947 \\
\hline N-PEN-01 & 0.0015 & 2.84 & 2.836 \\
\hline 2-MET-01 & 0.0032 & 6.18 & 6.178 \\
\hline N-HEX-01 & 0.0097 & 15.04 & 0.026 \\
\hline 2-MET-02 & 0.0098 & 15.34 & 0.028 \\
\hline N-HEP-01 & 0.0124 & 19.11 & 0.032 \\
\hline 2-MET-03 & 0.0133 & 20.65 & 0.036 \\
\hline N-OCT-01 & 0.0101 & 9.21 & 0.001 \\
\hline $2: 2: 4-01$ & 0.0143 & 13.53 & 0.002 \\
\hline N-NON-01 & 0.0066 & 10.01 & 0.014 \\
\hline $2: 2: 5-01$ & 0.0103 & 15.90 & 0.026 \\
\hline CYCLO-01 & 0.0033 & 0.91 & 0.072 \\
\hline METHY-01 & 0.0036 & 0.88 & 0.077 \\
\hline ETHYL-01 & 0.0049 & 0.31 & 0.012 \\
\hline N-PRO-01 & 0.0008 & 0.19 & 0.017 \\
\hline CYCLO-02 & 0.0000 & 0.08 & 0.081 \\
\hline METHY-02 & 0.0013 & 2.43 & 2.383 \\
\hline
\end{tabular}


Table 4. Cont.

\begin{tabular}{cccc}
\hline \multirow{2}{*}{ Components } & FEED & FBR (CPROD3) & FBMR (PROD3) \\
\cline { 2 - 4 } & Mole Fractions & $\mathbf{k m o l} / \mathbf{h}$ & $\mathbf{k m o l} / \mathbf{h}$ \\
\hline ETHYL-02 & 0.0028 & 5.25 & 5.091 \\
\hline N-PRO-02 & 0.0036 & 6.79 & 6.569 \\
\hline N-BUT-02 & 0.0005 & 0.97 & 0.938 \\
\hline BENZE-01 & 0.0036 & 19.40 & 205.080 \\
\hline TOLUE-01 & 0.0046 & 24.28 & 0.773 \\
\hline M-XYL-01 & 0.0006 & 9.01 & 5.561 \\
\hline O-XYL-01 & 0.0007 & 8.80 & 2.448 \\
\hline P-XYL-01 & 0.0015 & 12.45 & 0.679 \\
\hline ETHYL-03 & 0.0009 & 10.08 & 0.553 \\
\hline N-PRO-03 & 0.0011 & 9.97 & 0.065 \\
\hline HYDRO-01 & 0.8403 & 1866.82 & 595.781 \\
\hline
\end{tabular}

In Table 5, the output from the FBMR and FBR is summarized. The first column shows the quantity of aromatic and hydrogen in the feed. The second and third columns show the production rates of the respective component of the FBR and FBMR system. The calculated daily and yearly increase in aromatic and hydrogen is tabulated and used for the cost estimations of FBR and FBMR configuration.

Table 5. The net increment in aromatics and hydrogen.

\begin{tabular}{cccccc}
\hline & \multirow{2}{*}{$\begin{array}{c}\text { Feed } \\
\mathbf{( k g / h )}\end{array}$} & FBR & \multicolumn{2}{c}{ FBMR } & \multicolumn{2}{c}{ Increase Using the Membrane } \\
\cline { 3 - 6 } & & Out $\mathbf{( k g / h )}$ & Out (kg/h) & $\begin{array}{c}\text { Daily Increase } \\
\mathbf{( k g / d a y )}\end{array}$ & $\begin{array}{c}\text { Yearly Increase } \\
\mathbf{( k g} / \mathbf{Y})\end{array}$ \\
\hline Hydrogen & 3250 & $14,913.65$ & $17,080.07$ & 2166.42 & 790,743 \\
\hline Aromatics & 2374 & 4182.849 & 4267.602 & 84.753 & $30,934.84$ \\
\hline
\end{tabular}

\subsection{Thermoeconomic Analysis}

The physical and mixing exergy analysis is carried out at a reference temperature and pressure of $25^{\circ} \mathrm{C}$ and $101.3 \mathrm{kPa}$, respectively. The summary of the exergy analysis is provided in Table 6. Mustafa et al. [45] reported a detailed exergy analysis on the fluidized naphtha reforming process. Moreover, the authors mentioned that the mechanical and thermal exergies combine to form the physical exergy and that irreversible losses are mainly due to intertial and viscous resistances. As these resistances are significant in the reactor, a decrease in mechanical exergy is inevitable. In addition, due to the endothermic nature of reforming reactions, the physical exergy of the FBMR reactors decreases. Akram et al. and Mustafa et al. $[45,46]$ reported that most of the reactions in naphtha reforming are endothermic and lead to the decreased temperature, which in turn increases irreversibility. Therefore, due to this fact, irreversible losses result in decreased physical exergy.

The total capital investment and operating cost were calculated utilizing the straightline depreciation method for a time-horizon of 12 years. The income tax rate and interest rates are $45 \%$ and $10 \%$, respectively. The manpower costs are taken at a rate of $0.03 \%$. As per feed and product flow rates by model as well as their market values, annual gross sales are given in Tables 7 and 8 for FBR and FBMR, respectively. 
Table 6. Exergy analysis for FBR and FBMR.

\begin{tabular}{|c|c|c|c|c|c|c|c|}
\hline \multicolumn{8}{|c|}{ FBR } \\
\hline $\begin{array}{c}\text { Stream } \\
\text { Name }\end{array}$ & $\begin{array}{c}\mathrm{T} \\
(\mathrm{K})\end{array}$ & $\begin{array}{c}\mathrm{P} \\
(\mathrm{KPa})\end{array}$ & HR & SR & HS & SS & $\begin{array}{c}\text { Physical } \\
\text { Exergy }\end{array}$ \\
\hline FEED & 780 & 3702.991 & -26.7816 & -0.08856 & 5.069967 & -0.05384 & $11,468.25$ \\
\hline PROD1 & 770.025 & 3702.991 & -7.69063 & -0.03791 & 15.70902 & -0.02079 & $12,726.43$ \\
\hline PROD2 & 775.9731 & 3604.925 & -4.9959 & -0.02995 & 17.30305 & -0.01549 & $13,092.23$ \\
\hline PROD3 & 777.4178 & 3506.858 & -4.3791 & -0.02766 & 17.4909 & -0.01418 & $13,129.03$ \\
\hline \multicolumn{8}{|c|}{ FBMR } \\
\hline $\begin{array}{c}\text { Stream } \\
\text { Name }\end{array}$ & $\begin{array}{c}\mathrm{T} \\
(\mathrm{K})\end{array}$ & $\begin{array}{c}\mathrm{P} \\
(\mathrm{KPa})\end{array}$ & HR & SR & HS & SS & $\begin{array}{c}\text { Physical } \\
\text { Exergy }\end{array}$ \\
\hline FEED & 780 & 3702.991 & -26.7816 & -0.08856 & 5.069967 & -0.05384 & $11,468.25$ \\
\hline NETHYD1 & 776.9028 & 2800 & 0.000873 & $\begin{array}{c}-1.46 \times \\
10^{-06}\end{array}$ & 14.05493 & 0.000402 & 30.9085 \\
\hline NETHYD2 & 776.9891 & 900 & 0.000873 & $\begin{array}{c}-1.46 \times \\
10^{-06}\end{array}$ & 14.0306 & 0.009842 & 2540.903 \\
\hline NETHYD3 & 777.0001 & 900 & 0.000873 & $\begin{array}{c}-1.46 \times \\
10^{-06}\end{array}$ & 14.03092 & 0.009842 & 2122.787 \\
\hline PROD1 & 776.4373 & 3702.991 & -5.83885 & -0.03361 & 17.30526 & -0.01722 & $13,053.95$ \\
\hline PROD2 & 776.9417 & 3604.925 & -7.23389 & -0.04482 & 19.21282 & -0.02147 & 9810.164 \\
\hline PROD3 & 777.0003 & 3506.858 & -12.8969 & -0.07652 & 21.80172 & -0.03476 & 7016.567 \\
\hline
\end{tabular}

$\mathrm{HR}=$ Enthalpy at reference state, $\mathrm{SR}=$ Entropy at reference state, $\mathrm{HS}=$ Enthalpy in stream condition, SS= Entropy in stream condition

Table 7. Gross annual sales of FBR.

\begin{tabular}{cccc}
\hline & \multicolumn{2}{c}{ Gross Annual Sales of FBR } & \\
\hline Material Name & $\begin{array}{c}\text { Price } \\
\mathbf{( \$ / k g )}\end{array}$ & $\begin{array}{c}\text { Flow Rate } \\
\mathbf{( k g / h )}\end{array}$ & Annual Cost \\
\hline Naphtha & 0.30 & $28,178.00$ & $70,349,195$ \\
\hline Natural gas & 0.00254 & 4790.505 & 79,733 \\
\hline Gasoline & 0.90 & 6523.001 & $48,855,965$ \\
\hline Aromatics & 0.99 & $14,913.65$ & $123,125,549$ \\
\hline Hydrogen & 1.80 & 4182.849 & $62,644,687$ \\
\hline
\end{tabular}

Table 8. Gross annual sales of FBMR.

\begin{tabular}{|c|c|c|c|}
\hline \multicolumn{4}{|c|}{ Gross Annual Sales of FBMR } \\
\hline Material Name & $\begin{array}{l}\text { Price } \\
(\$ / k g)\end{array}$ & $\begin{array}{c}\text { Flow Rate } \\
(\mathrm{kg} / \mathrm{h})\end{array}$ & Annual Cost \\
\hline Naphtha & 0.30 & $28,178.00$ & $70,349,195$ \\
\hline Natural Gas & 0.00254 & $7,466.072$ & 155,330 \\
\hline Gasoline & 0.90 & $1,596.609$ & $11,953,721$ \\
\hline Aromatics & 0.99 & $17,080.07$ & $140,718,362$ \\
\hline Hydrogen & 1.80 & $4,267.602$ & $62,926,971$ \\
\hline
\end{tabular}

The detailed work of the Direct Cost (costs for equipment, piping, civil, structural steel, instrumentation and controls, electrical equipment and materials, insulation, and paint), labour cost, chemicals, and catalyst, etc., is performed utilizing factors from Table 3. 
The CEPCI index for the year 2020 is 589.4. Table 9 shows the detailed equipment cost comparisons of FBR and FBMR. The thermal utility used in FBR and FBMR is the same, which is why both have the same utility cost. Moreover, the working capital is the same for both FBR and FBMR. The Lang factor cost clearly shows the difference between the cost for complete projects. The difference is for FBMR due to the membrane addition, which resulted in the increased cost.

Table 9. Cost comparison of FBMR and FBR.

\begin{tabular}{ccc}
\hline Cost & FBMR & FBR \\
\hline Equipment cost & $\$ 42,904,400$ & $\$ 29,904,400$ \\
\hline Bare module cost & $\$ 65,575,400$ & $\$ 45,575,400$ \\
\hline Total module & $\$ 77,378,972$ & $\$ 53,778,972$ \\
\hline Total grass root cost & $\$ 77,550,922$ & $\$ 53,950,922$ \\
\hline Lang factor & 4.74 & 4.74 \\
\hline Lang factor cost & $\$ 203,366,856$ & $\$ 141,746,856$ \\
\hline Raw materials costs & $\$ 70,349,195$ & $\$ 70,349,195$ \\
\hline Working capital & $\$ 22,100,000$ & $\$ 22,100,000$ \\
\hline Cost of utilities & $\$ 866,000$ & $\$ 866,000$ \\
\hline Cost of operating labor & $\$ 802,920$ & $\$ 802,890$ \\
\hline Cost of manufacturing & $\$ 117,079,279$ & $\$ 116,810,749$ \\
\hline Revenue from Sales & $\$ 216,754,384$ & $\$ 234,705,934$ \\
\hline
\end{tabular}

The cost of manufacturing (COM) is calculated by Equation (8), here $C_{W T}$ is considered as zero.

$$
C O M=0.18 C_{C I L}+2.76 C_{O L}+1.23\left(C_{U T I L I T Y}+C_{W T}+C_{R M}\right)
$$

$C_{O L}$ is the cost of operating labour, $C_{\text {UTILITY }}$ is the cost of utility, $C_{W T}$ is the waste treatment cost, and $C_{R M}$ is the raw material cost.

For a profitability analysis, discounted cumulative cash flow diagrams for 12 years with an initial construction period of 2 years are constructed, as shown in Figure 11 for FBMR and FBR. The highest discounted cash cumulative cash position, also known as the net present value (NPV), of USD 160.19 million for FBMR and USD 215.48 million for FBR is given in Tables 10 and 11, respectively. As per the discounted profitability criteria, the payback period of 3.6 and 2.6 years are obtained for both FBMR and FBR, respectively.

Table 10. Profitability criteria for FBMR.

\begin{tabular}{cc}
\hline \multicolumn{2}{c}{ Discounted Profitability Criteria } \\
\hline Net Present Value (millions) & 160.19 \\
\hline Discounted Cash Flow Rate of Return & $26.17 \%$ \\
\hline Discounted Payback Period (years) & 3.2 \\
\hline Non-Discounted Profitability Criteria \\
\hline Cumulative Cash Position (million) & 465.31 \\
\hline Rate of Return on Investment & $31.02 \%$ \\
\hline Payback Period (years) & 2.5 \\
\hline
\end{tabular}




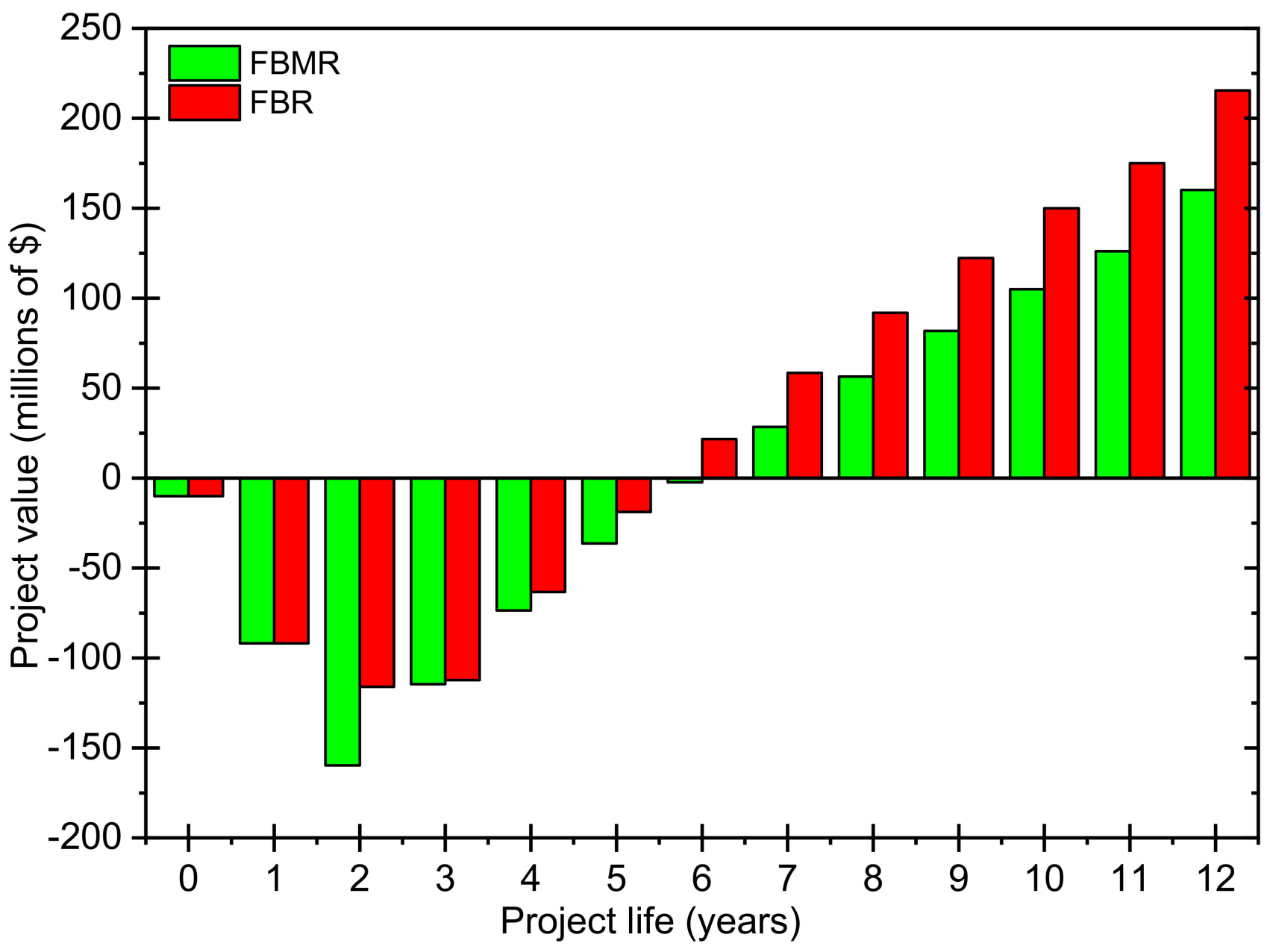

Figure 11. Cumulative cash flow diagram for FBMR and FBR.

Table 11. Profitability criteria for FBR.

\begin{tabular}{cc}
\hline \multicolumn{2}{c}{ Discounted Profitability Criteria } \\
\hline Net Present Value (millions) & 215.48 \\
\hline Discounted Cash Flow Rate of Return & $30.24 \%$ \\
\hline Discounted Payback Period (years) & 2.6 \\
\hline Non-Discounted Profitability Criteria \\
\hline Cumulative Cash Position (million) & 582.09 \\
\hline Rate of Return on Investment & $38.81 \%$ \\
\hline Payback Period (years) & 2.1 \\
\hline
\end{tabular}

\section{Conclusions}

A fluidized bed naphtha reformer with the in-situ membrane separation model is developed in the Aspen Plus environment. The hydrodynamic parameters and membrane permeation phenomena are implemented using Excel interfacing. The results of the fluidized bed membrane reactor (FBMR) are compared with a simple fluidized bed reactor (FBR). It is observed that hydrogen removal from the permeate side drove the reaction forward and resulted in an increase in the aromatic yield. The physical exergy of the outlet stream of FBMR is lesser than that of FBR, due to the higher irreversibility in the reactor. The cost analysis shows that the Lang factor cost is USD 203.36 and 141.74 MM for the FBMR and FBR, respectively. The cost of manufacturing for FBMR and FBR are USD 117.08 
and 116.81 MM/year, respectively. Moreover, the net revenue generated by FBMR and FBR is USD 216,754,384 and 234,705,934, respectively. Furthermore, the FBMR and FBR had a payback period of 3.2 and 2.6 years, respectively.

Author Contributions: Conceptualization, T.N., A.A.B. and I.A.; methodology, T.N. and A.A.B.; software, T.N. and A.A.B.; validation, T.N., A.A.B. and U.K.J.; formal analysis, T.N., A.A.B. and U.K.J.; investigation, T.N., A.A.B. and U.K.J.; resources, I.A. and M.K.; data curation, T.N.; writing-original draft preparation, T.N. and U.K.J.; writing-review and editing, I.A., N.u.H.S., M.K., B.C.M., M.A. and F.A.; visualization, A.A.B., T.N. and I.A.; supervision, I.A.; All authors have read and agreed to the published version of the manuscript.

Funding: This study is supported by the Higher Education Commission (HEC), Pakistan, under the National Research Program for Universities (NRPU) Project No. 6016/ Federal.

Institutional Review Board Statement: Not applicable.

Informed Consent Statement: Not applicable

Data Availability Statement: Not applicable

Acknowledgments: The authors would like to give special thanks to Higher Education Commission (HEC), Pakistan for funding this work.

Conflicts of Interest: The authors declare no conflict of interest.

\section{Nomenclature}

Ac cross section of reactor, $\mathrm{m}^{2}$

CSTR continuous stirred tank reactor

$\mathrm{db}$ bubble diameter, $\mathrm{m}$

$\mathrm{Ei} \quad$ activation energy for the $\mathrm{i}^{\text {th }}$ reaction, $\mathrm{kJ} / \mathrm{kmol}$

Ep activation energy of permeability, $\mathrm{kJ} / \mathrm{mol}$

FBP final boiling pint $\left({ }^{\circ} \mathrm{C}\right)$

$\mathrm{FSH}_{2}$ flow rate of $\mathrm{H}_{2}$ in shell side gas, $\mathrm{kmol} / \mathrm{h}$

$\mathrm{Ft}$ total molar flow rate, $\mathrm{kmol} / \mathrm{h}$

IBP initial boiling point, ${ }^{\circ} \mathrm{C}$

$\mathrm{RON}$ research octane number

kci coefficient for mass transfer of specie $i, m / h$

Kei equilibrium coefficient

$\mathrm{kfi}$ forward rate constant

$\mathrm{L} \quad$ length of reactor, $\mathrm{m}$

MR membrane reactor

pi partial pressure of specie $\mathrm{i}, \mathrm{kPa}$

$\mathrm{Pt}$ total pressure, $\mathrm{kPa}$

$\mathrm{pRH}_{2}$ reaction side hydrogen partial pressure, $\mathrm{Pa}$

$\mathrm{pS}_{2}$ shell side hydrogen partial pressure, $\mathrm{Pa}$

$\mathrm{P}$ permeability of hydrogen through $\mathrm{Pd}-\mathrm{Ag}$ layer, $\mathrm{mol} / \mathrm{m}^{2} \mathrm{~s} \mathrm{~Pa}^{0}{ }^{5}$

$\mathrm{P}_{0} \quad$ pre-exponential factor of hydrogen permeability, $\mathrm{mol} / \mathrm{m}^{2} \mathrm{~s} \mathrm{~Pa}^{0}{ }^{5}$

PBR packed bed reactor

PFR plug flow reactor

$\mathrm{R} \quad$ gas constant, $\mathrm{kJ} / \mathrm{kmol} \mathrm{K}$

ri rate of reaction for the i reaction, $\mathrm{kmol} / \mathrm{kg}$ cat $\mathrm{h}$

$\mathrm{T}$ temperature of gas phase, $\mathrm{K}$

TBP true boiling point, ${ }^{\circ} \mathrm{C}$

$\mathrm{t}$ time, $\mathrm{h}$

$\mathrm{ub} \quad$ velocity of rise of bubbles, $\mathrm{m} \mathrm{s}^{-1}$

Cmp membrane permeation capacity (membrane surface area/thickness)

$\mathrm{Ep} \quad$ activation energy for permeation, $\mathrm{J} \mathrm{mol}^{-1}$

$\mathrm{k}$ pre-exponential factor, $\mathrm{mol} \mathrm{km} \mathrm{km}^{-1} \mathrm{~h}^{-1} \mathrm{~Pa}^{-0}{ }^{5}$ 


$\begin{array}{ll}\text { Greek letters } & \\ \alpha \mathrm{H} & \text { hydrogen permeation rate constant, } \mathrm{mol} / \mathrm{m} \mathrm{s} \mathrm{Pa}^{0} .^{5} \\ \mathrm{~d} & \text { thickness of palladium layer, } \mathrm{mm} \\ \rho \mathrm{b} & \text { catalyst bed density, } \mathrm{kg} / \mathrm{m}^{3} \\ \rho \mathrm{g} & \text { density of gas phase, } \mathrm{kg} / \mathrm{m}^{3} \\ \mathrm{vij} & \text { stoichiometric coefficient of specie i in reaction } \mathrm{j} \\ \Delta \mathrm{H} & \text { heat of reaction, } \mathrm{kJ} / \mathrm{kmol} \\ \varepsilon \mathrm{b} & \text { void fraction of catalyst bed } \\ \varepsilon \mathrm{mf} & \text { void fraction of catalytic bed at minimum fluidization } \\ \varphi & \text { catalyst particle shape factor } \\ \delta & \text { fraction of gas in bubble phase } \\ \eta & \text { permeation effectiveness factor }\end{array}$

\section{References}

1. Rahimpour, M.R.; Jafari, M.; Iranshahi, D. Progress in Catalytic Naphtha Reforming Process: A Review. Appl. Energy 2013, 109, 79-93. [CrossRef]

2. Patil, C.S.; van Sint Annaland, M.; Kuipers, J.A. Design of a Novel Autothermal Membrane-Assisted Fluidized-Bed Reactor for the Production of Ultrapure Hydrogen from Methane. Ind. Eng. Chem. Res. 2005, 44, 9502-9512. [CrossRef]

3. McKetta, J., Jr. Encyclopedia of Chemical Processing and Design: Volume 48-Residual Refining and Processing to Safety: Operating Discipline; Routledge: Oxfordshire, UK, 2017.

4. Shu, J.; Grandjean, B.P.; Kaliaguine, S. Methane Steam Reforming in Asymmetric Pd-and Pd-Ag/Porous SS Membrane Reactors. Appl. Catal. A Gen. 1994, 119, 305-325. [CrossRef]

5. Helmi, A.; Fernandez, E.; Melendez, J.; Pacheco Tanaka, D.A.; Gallucci, F.; van Sint Annaland, M. Fluidized Bed Membrane Reactors for Ultra Pure H2 Production-A Step Forward towards Commercialization. Molecules 2016, 21, 376. [CrossRef]

6. Rahimpour, M.R. Enhancement of Hydrogen Production in a Novel Fluidized-Bed Membrane Reactor for Naphtha Reforming. Intern. J. Hydrog. Energy 2009, 34, 2235-2251. [CrossRef]

7. Rahimpour, M.R.; Iranshahi, D.; Pourazadi, E.; Bahmanpour, A.M. A Comparative Study on a Novel Combination of Spherical and Membrane Tubular Reactors of the Catalytic Naphtha Reforming Process. Intern. J. Hydrog. Energy 2011, 36, 505-517. [CrossRef]

8. Keuler, J.N.; Lorenzen, L. Comparing and Modeling the Dehydrogenation of Ethanol in a Plug-Flow Reactor and a Pd- Ag Membrane Reactor. Ind. Eng. Chem. Res. 2002, 41, 1960-1966. [CrossRef]

9. Howard, B.H.; Killmeyer, R.P.; Rothenberger, K.S.; Cugini, A.V.; Morreale, B.D.; Enick, R.M.; Bustamante, F. Hydrogen Permeance of Palladium-Copper Alloy Membranes over a Wide Range of Temperatures and Pressures. J. Membr. Sci. 2004, 241, 207-218. [CrossRef]

10. Barbieri, G.; Di Maio, F.P. Simulation of the Methane Steam Re-Forming Process in a Catalytic Pd-Membrane Reactor. Ind. Eng. Chem. Res. 1997, 36, 2121-2127. [CrossRef]

11. Rahimpour, M.R.; Vakili, R.; Pourazadi, E.; Iranshahi, D.; Paymooni, K. A Novel Integrated, Thermally Coupled Fluidized Bed Configuration for Catalytic Naphtha Reforming to Enhance Aromatic and Hydrogen Productions in Refineries. Intern. J. Hydrog. Energy 2011, 36, 2979-2991. [CrossRef]

12. Pasha, M.K.; Ahmad, I.; Mustafa, J.; Kano, M. Modeling of a Nickel-Based Fluidized Bed Membrane Reactor for Steam Methane Reforming Process. J. Chem. Soc. Pakistan 2019, 41, 219-229.

13. Tosti, S.; Basile, A.; Bettinali, L.; Borgognoni, F.; Gallucci, F.; Rizzello, C. Design and Process Study of Pd Membrane Reactors. Intern. J. Hydrog. Energy 2008, 33, 5098-5105. [CrossRef]

14. Roy, S.; Cox, B.G.; Adris, A.M.; Pruden, B.B. Economics and Simulation of Fluidized Bed Membrane Reforming. Intern. J. Hydrog. Energy 1998, 23, 745-752. [CrossRef]

15. Mostafazadeh, A.K.; Rahimpour, M.R. A Membrane Catalytic Bed Concept for Naphtha Reforming in the Presence of Catalyst Deactivation. Chem. Eng. Process. 2009, 48, 683-694. [CrossRef]

16. Itoh, N. Inorganic Membranes for Reaction and Separation. AIChE J. 1987, 33, 1576. [CrossRef]

17. Mazzieri, V.A.; Pieck, C.L.; Vera, C.R.; Yori, J.C.; Grau, J.M. Effect of Ge Content on the Metal and Acid Properties of Pt-ReGe/Al2O3-Cl Catalysts for Naphtha Reforming. Appl. Catal., A: General 2009, 353, 93-100. [CrossRef]

18. Van Gool, W. Exergy Analysis of Industrial Processes. Energy 1992, 17, 791-803. [CrossRef]

19. Gilbert, A.; Mesmer, B.; Watson, M.D. Uses of Exergy in Systems Engineering. In Proceedings of the 2016 Conference on Systems Engineering Research, Huntsville, AL, USA, 22-24 March 2016; pp. 22-24.

20. Nimkar, S.C.; Mewada, R.K. An Overview of Exergy Analysis for Chemical Process Industries. Int. J. Exergy 2014, 15, 468-507. [CrossRef]

21. Montelongo-Luna, J.M.; Svrcek, W.Y.; Young, B.R. An Exergy Calculator Tool for Process Simulation. Asia Pac. J. Chem. Eng. 2007, 2, 431-437. [CrossRef]

22. Hinderink, A.P.; Kerkhof, F.; Lie, A.B.K.; Arons, J.D.S.; Van Der Kooi, H.J. Exergy Analysis with a Flowsheeting Simulator-I. Theory; Calculating Exergies of Material Streams. Chem. Eng. Sci. 1996, 51, 4693-4700. [CrossRef] 
23. Hinderink, A.P.; Kerkhof, F.; Lie, A.B.K.; Arons, J.D.S.; Van Der Kooi, H.J. Exergy Analysis with a Flowsheeting Simulator-II. Application; Synthesis Gas Production from Natural Gas. Chem. Eng. Sci. 1996, 51, 4701-4715. [CrossRef]

24. Sarvar-Amini, A.; Sotudeh-Gharebagh, R.; Bashiri, H.; Mostoufi, N.; Haghtalab, A. Sequential Simulation of a Fluidized Bed Membrane Reactor for the Steam Methane Reforming Using ASPEN PLUS. Energy Fuels 2007, 21, 3593-3598. [CrossRef]

25. Samoila, P.; Boutzeloit, M.; Benitez, V.; D’Ippolito, S.A.; Especel, C.; Epron, F.; Vera, C.R.; Marecot, P.; Pieck, C.L. Influence of the Pretreatment Method on the Properties of Trimetallic Pt-Ir-Ge/Al2O3 Prepared by Catalytic Reduction. Appl. Catal. A: General 2007, 332, 37-45. [CrossRef]

26. Murzin, D.Y. Selectivity of Complex Heterogeneous Catalytic Reactions over Energetically Nonuniform Surfaces. React. Kinet. Catal. Lett. 1996, 59, 117-123. [CrossRef]

27. Smith, R.B. Kinetic Analysis of Naphtha Reforming with Platinum Catalyst. Chem. Eng. Prog 1959, 55, 76-80.

28. Marin, G.B.; Froment, G.F.; Lerou, J.J.; De Backer, W. Simulation of a Catalytic Naphtha Reforming Unit. Eur. Fed. Chem. Eng. $1983,1-7$.

29. Ramage, M.P.; Graziani, K.R.; Krambeck, F.J. 6 Development of Mobil's Kinetic Reforming Model. Chem. Eng. Sci. 1980, 35, 41-48. [CrossRef]

30. Ancheyta-Juarez, J.; Villafuerte-Macías, E. Kinetic Modeling of Naphtha Catalytic Reforming Reactions. Energy Fuels 2000, 14, 1032-1037. [CrossRef]

31. Hu, Y.; Xu, W.; Su, H.; Chu, J. A Dynamic Model for Naphtha Catalytic Reformers. In Proceedings of the 2004 IEEE International Conference on Control Applications, Taipei, Taiwan, 2-4 September 2004; Volume 1, pp. 159-164.

32. Vathi, G.P.; Chaudhuri, K.K. Modelling and Simulation of Commercial Catalytic Naphtha Reformers. Can. J. Chem. Eng. 1997, 75, 930-937. [CrossRef]

33. Hou, W.; Su, H.; Hu, Y.; Chu, J. Modeling, Simulation and Optimization of a Whole Industrial Catalytic Naphtha Reforming Process on Aspen Plus Platform. Chin. J. Chem. Eng. 2006, 14, 584-591. [CrossRef]

34. Yun, S.; Ted Oyama, S. Correlations in Palladium Membranes for Hydrogen Separation: A Review. J. Membr. Sci. 2011, 375, 28-45. [CrossRef]

35. Vadrucci, M.; Borgognoni, F.; Moriani, A.; Santucci, A.; Tosti, S. Hydrogen Permeation through Pd-Ag Membranes: Surface Effects and Sieverts' Law. Int. J. Hydrogen Energy 2013, 38, 4144-4152. [CrossRef]

36. Mori, S.; Wen, C.Y. Estimation of Bubble Diameter in Gaseous Fluidized Beds. AIChE J. 1975, 21, 109-115. [CrossRef]

37. Querol, E.; Gonzalez-Regueral, B.; Ramos, A.; Perez-Benedito, J.L. Novel Application for Exergy and Thermoeconomic Analysis of Processes Simulated with Aspen Plus ${ }^{\circledR}$. Energy 2011, 36, 964-974. [CrossRef]

38. Guthrie, K.M. Capital Cost Estimation. Chem. Engng. 1969, 24, 114-142.

39. Smith, R. Chemical Process: Design and Integration; John Wiley \& Sons: Hoboken, NJ, USA, 2005.

40. Shabani, M.R.; Yekta, R.B. Chemical Processes Equipment Cost Estimating Using Parametric Models. Cost Eng. Ann. Arbor Then Morgant. 2006, 48, 26.

41. Lang, H.J. Cost Relationships in Preliminary Cost Estimation. Chem. Eng 1947, 54, 117-121.

42. Tamhankar, S.; Gulamhusein, A.; Boyd, T.; DaCosta, D.; Golben, M. DOE Hydrogen, Fuel Cells and Infrastructure Technologies Program Integrated Hydrogen Production, Purification and Compression System; Linde LLC: Guildford, UK, 2011.

43. Wieland, S.; Melin, T.; Lamm, A. Membrane Reactors for Hydrogen Production. Chem. Eng. Sci. 2002, 57, 1571-1576. [CrossRef]

44. Tong, J.; Matsumura, Y. Pure Hydrogen Production by Methane Steam Reforming with Hydrogen-Permeable Membrane Reactor. Catal. Today 2006, 111, 147-152. [CrossRef]

45. Mustafa, J.; Ahmad, I.; Ahsan, M.; Kano, M. Computational Fluid Dynamics Based Model Development and Exergy Analysis of Naphtha Reforming Reactors. Int. J. Exergy 2017, 24, 344-363. [CrossRef]

46. Akram, A.U.; Ahmad, I.; Chughtai, A.; Kano, M. Exergy Analysis and Optimisation of Naphtha Reforming Process with Uncertainty. Int. J. Exergy 2018, 26, 247-262. [CrossRef] 